EPOS, XV (1999), págs. 481-537

\title{
PUBLICACIONES SOBRE FILOLOGÍA GRIEGA EN ESPAÑA (1998)
}

\author{
Helena Rodríguez Somolinos
}

UNED. Madrid

\section{ORganización}

1. Actas de congresos. Homenajes. Volúmenes colectivos

2. AutORES ANTIGUOS. EDICIONES, TRADUCCIONES Y ESTUdIOS

3. Historia dE LA LITERATURA

4. LINGÜISTICA GRIEGA

5. Micenología

6. Epigrafía. Papirología

7. Historia de los teXtos

8. Historia. Cultura. Sociedad

9. Religión. Mitología

10. Filosofía. Ciencia

11. Pervivencia. Humanismo. Historia de la filología

12. Diccionarios. Repertorios. Otros InStRUMENTOS

13. Didáctica 


\section{REVISTAS}

$A M:$

Analecta Malacitana. Universidad de Málaga. Facultad de Filosofía y Letras. Sección de Filología.

CFCG: Cuadernos de Filología Clásica. Estudios Griegos e Indoeuropeos. Universidad Complutense de Madrid. Facultad de Filología.

CFCL: $\quad$ Cuadernos de Filología Clásica. Estudios Latinos. Universidad Complutense de Madrid. Facultad de Filología.

$E B$ : Estudios Biblicos. Madrid. C.S.I.C. Patronato Menéndez Pelayo. Instituto Francisco Suárez.

EClás.: $\quad$ Estudios Clásicos. Madrid, Sociedad Española de Estudios Clásicos.

Emerita: Emerita. Revista de Linguística y Filología Clásica. Madrid, C.S.I.C. Instituto de Filología.

Epos: $\quad$ Epos. Revista de Filología. Madrid. Universidad Nacional de Educación a Distancia. Facultad de Filología.

Exc.Phil.: Excerpta Philologica. Revista de Filología Griega y Latina. Universidad de Cádiz.

Faventia: Faventia. Universitat Autònoma de Barcelona. Facultat de Lletres. Dpto. de Filología Clásica.

FN: $\quad$ Filología Neotestamentaria. Universidad de Córdoba. Facultad de Filosofía y Letras.

FI: Florentia lliberritana. Revista de Estudios de Antigüedad Clásica. Universidad de Granada.

Fortunatae: Fortunatae. Revista canaria de filología, cultura y humanidades clásicas. Universidad de la Laguna. Dpto. de Filología Clásica y Arabe.

Gerión: Gerión. Universidad Complutense de Madrid. Dpto. de Historia Antigua.

Habis: $\quad$ Habis. Universidad de Sevilla.

Helmantica: Helmantica. Revista de Filología Clásica y Hebrea. Universidad Pontificia de Salamanca.

'Ilu: 'llu. Revista de Ciencias de las Religiones. Universidad Complutense de Madrid. Instituto Universitario de Ciencias de las Religiones.

MHA: $\quad$ Memorias de Historia Antigua. Universidad de Oviedo. Instituto de Historia Antigua.

Minerva: Minerva. Revista de Filología Clásica. Universidad de Valladolid. Dpto. de Filología Clásica. 
Minos: $\quad$ Minos. Revista de Filología Egea. Universidad de Salamanca y Myrtia: $\quad$ Myrtia. Universidad de Murcia.

Perficit: Perficit. Publicación de Estudios Clásicos. Textos y Estudios.

Polis: $\quad$ Polis. Revista de ideas y formas políticas Salamanca.

R.S.E.L.: Revista Española de Lingüística. Organo de la Sociedad Española de Linguíística. Madrid, Editorial Gredos.

SPhV:

Tempus: Studia Philologica Valentina. Universidad de Valencia. Tempus. Revista de actualización científica. Madrid. Ediciones Veleia. Revista de Prehistoria, Historia Antigua, Arqueología y Filología Clásica. Vitoria. Universidad del País Vasco. Instituto de Ciencias de la Antiguiedad.

\section{ACtas de Congresos. Homenajes. Volúmenes Colectivos}

Adrados, F.R.; Martínez Díez, A. (eds.): Actas del IX Congreso Español de Estudios Clásicos (Madrid, 27-30 de Septiembre 1995). Volumen IV: Literatura Griega. Madrid, Ediciones Clásicas, 1998 (= Actas del IX Congreso IV).

Alvar Ezquerra, A.; García Fernández, J. (eds.): Actas del IX Congreso Español de Estudios Clásicos (Madrid, 27-30 de Septiembre de 1995). Volumen III: Lingüística Latina. Madrid, Ediciones Clásicas, 1998 (= Actas del IX Congreso III).

Alvar Ezquerra, A.; García Fernández, J.; González Castro, J.F. (eds.): Actas del IX Congreso Español de Estudios Clásicos (Madrid, 27-30 de Septiembre de 1995). Volumen VII: Humanismo y Tradición Clásica. Madrid, Ediciones Clásicas, 1998 (= Actas del IX Congreso VII).

Brioso, M.; GonzÁlez PonCE, F.J. (EDs.): Actitudes literarias en la Grecia romana. Sevilla, Pórtico, 1998 (= Actitudes literarias).

CAlvo MARTínez, J.L. (ed.): Religión, magia y mitología en la antigüedad clásica. Granada, Universidad, 1998 (=Religión, magia y mitología).

Estefanía, M.D.; DomínguEz, M.; Amado, M.T. (eds.): Géneros literarios poéticos grecolatinos. Cuadernos de Literatura Griega y latina II. Madrid Santiago de Compostela, Delegación Gallega de la S.E.E.C. - Universidad de Santiago, 1998 (= Géneros literarios poéticos). 
Fernández de Mier, E.; Piñero, F. (eds.): Amores míticos. Madrid, S.E.E.C. Ediciones Clásicas, 1998 (= Amores míticos).

García Novo, E.; Rodríguez Alfageme, 1. (eds.): Dramaturgia y puesta en escena en el teatro griego - Dramaturgia e messa in scena nel teatro greco. Primer coloquio italo-español sobre el teatro griego (Madrid, 9-11 de Marzo de 1995). Madrid, Ediciones Clásicas, 1998 (= Dramaturgia y puesta en escena).

Gil, L.; Martínez Pastor, M.; Agullar, R.M. (eds.): Corolla Complutensis in memoriam Iosephi S. Lasso de la Vega contexta. Madrid, Universidad Complutense, 1998 (= Corolla Complutensis).

González CaStro, J.F. (ed.): Actas del IX Congreso Español de Estudios Clásicos (Madrid, 27-30 de Septiembre de 1995). Volumen VI: Historia y Arqueología. Madrid, Ediciones Clásicas, 1998 (= Actas del IX Congreso VI).

LÓPEZ FÉREZ, J.A. (ed.): La comedia griega y su influencia en la literatura española. Madrid, Ediciones Clásicas, 1998 (= La comedia griega y su influencia).

Pérez Jiménez, A.; Cruz ANDreotti, G. (eds.): Los límites de la tierra: el espacio geográfico en las culturas mediterráneas. Madrid, Ediciones Clásicas, 1998 (= Los límites de la tierra).

López Eire, A.; Labiano Ilundain, J.M.; Seoane Pardo, A.M. (eds.): Retórica, política e ideología desde la Antigüedad hasta nuestros días. Vol. I: Retórica clásica y Edad Media; Vol. II: Desde la modernidad hasta nuestros días. Actas del Il Congreso internacional (Salamanca, Noviembre de 1997). Salamanca, Asociación Española de Estudios sobre Lengua, Pensamiento y Cultura Clásica, 1998 (= Retórica, Política e ideología I y II).

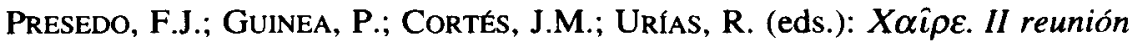
de historiadores del mundo griego antiguo (Sevilla, 18-21 de Diciembre de 1995). Homenaje al profesor Fernando Gascó. Sevilla, Scriptorium,

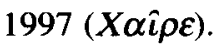

SCHRADER, C.; JoRdÁN, C.; BelTRÁN, J.A.: $\Delta t \delta a ́ \alpha \kappa \alpha \lambda o \zeta$. Estudios en homenaje al profesor Serafín Agud con motivo de su octogésimo aniversario. Zaragoza, Universidad, 1998 (= $\Delta \mathrm{l} \delta \alpha \sigma \sigma \alpha \alpha \lambda o \varsigma)$.

TORREGo, M.E. (ed.): Nombres y funciones. Estudios de sintaxis griega y latina. Madrid, Universidad Autónoma - Ediciones Clásicas, 1998 (= Nombres y funciones).

VIDAl, J.L.; Alvar Ezquerra, A. (eds.): Actas del IX Congreso Español de Estudios Clásicos (Madrid, 27-30 de Septiembre de 1995). Volumen V: Literatura Latina. Madrid, Ediciones Clásicas, 1998 (= Actas del IX Congreso V). 
2. Autores ANTIGUOS. EDICIONES, TRADUCCIONES Y ESTUDIOS

\section{Acta Apostolorum Apocrypha}

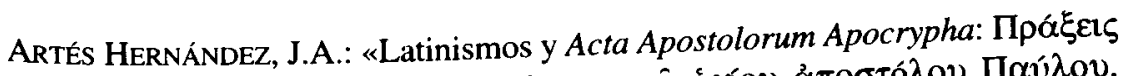

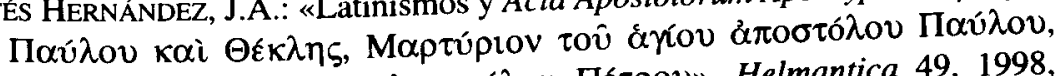

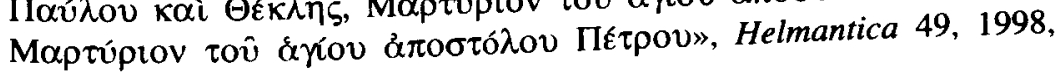
285-307.

Artés HernándeZ, J.A.: «Evangelios canónicos y Acta Apostolorum Apocrypha: estudio de algunos lugares paralelos», FN 11(21-22), 1998, 25-41.

Pedregal, A.: «Tecla de Iconio: la amenaza de la doble transgresión», X $\alpha \hat{\imath} \rho \varepsilon$ 527-536.

\section{Acusilaus}

Merino Martínez, J.I.: «Acusilao de Argos. Significado político de su genealogía argiva», Actas del IX Congreso VI, 177-180.

\section{Aeschines}

García Ruiz, M.: «El empleo de sentencias en los Discursos II y III de Esquines y XVIII y XIX de Demóstenes», Corolla Complutensis 305-310.

MARTín Velasco, M.J.: "Sintaxis y argumentación en el Contra Ctesifonte de Esquines», Epos 13, 1997, 13-29.

\section{Aeschylus}

Bañuls Oller, J.V.: «Esquilo, Suplicantes 867-871 877-881», Actas del IX Congreso IV, 65-69.

Díaz Tejera, A.; Moreno Arribas, G.: «Esquilo, Agamenón 414-415», Corolla Complutensis 147-154.

EsQuilo: La Orestea (Agamenón, Coéforos, Euménides). Edición de J.L. de Miguel Jover. Madrid, Akal, 1998

García Romero, F.: «Esquilo, Suplicantes 524-536: análisis métrico», Corolla Complutensis 377-282.

GARZyA, A.: «Considerazioni sul tragico in Eschilo (e in Camus)», Corolla Complutensis 155-160.

LUCIA, R. DE: «Il processo ad Oreste nelle Eumenidi di Eschilo», Dramaturgia y puesta en escena $85-98$. 
Morenilla TAlens, C.: «Los textos a través de los textos: Esquilo en el De sublimitate", Actas del IX Congreso IV, 259-263.

Vílchez, M.: «Anticipo de mi edición y traducción de Esquilo», Actas del IX Congreso IV, 357-360.

\section{Aesopus et Aesopica}

Esopo: Fábulas. Introducción, traducción y notas de G. López Casildo. Madrid, Alianza, 1998.

Esopo: Fábulas. Madrid, Edimat, 1998.

ESOPO: Fábulas completas. Madrid, Edimat, 1998.

ESOPO Y FEDRO: Fábulas. Madrid, Ediciones Internacionales Universitarias, 1998. VAN DiJK, G.-J.: «Suplemento al inventario de la fábula greco-latina. Épocas arcaica, clásica y helenística», Emerita 66, 1998, 15-22.

\section{Alcaeus}

Rodríguez Somolinos, H.: El léxico de los poetas lesbios. Diccionario Griego Español, Anejo IV. Madrid, Consejo Superior de Investigaciones Científicas, 1998.

\section{Alcidamas}

Guillén DE LA NAVA, M.: «La retórica de los escritos contra la retórica de lo hablado en Alcidamante de Élide», Retórica, política e ideología I, 85-90.

\section{Alcman}

MARTínez NiETo, R.B.: «Пб́pos: una divinidad cosmogónica olvidada», Actas del IX Congreso IV, 229-233.

\section{Ammonius philosophus}

FERNÁNDEZ GARRIDO, R.: La reflexión lingüística en el último neoplatonismo. Introducción, traducción y notas del comentario de Ammonio al tratado Sobre la interpretación de Aristóteles (Ammon, in Int. 1-77,25 Busse). Huelva, Universidad, 1998. 


\section{Anthologia Graeca}

Álvarez Siverio, C.: «La mujer en los poetas epigramáticos de La Guirnalda de Filipo de Tesalónica», Actas del IX Congreso IV, 45-48.

LAGUNA MARISCAL, G.: "La poesía epigramática griega en su relación con la literatura romana: el tema amoroso", Actitudes literarias 93-121.

Pérez Cabrera, J.: "Mujeres y ritos fúnebres en el epigrama helenístico», Actas del IX Congreso IV, 277-280.

WHITE, H.: «An Epigram for an Emperor», Veleia 15, 1998, 391-392.

WhITE, H.: «Two Obscene Epigrams by Rufinus», Veleia 15, 1998, 393-396.

\section{Antipho}

Gastaldi, V.; Gambon, L.: «Algunas consideraciones en torno a $\beta o u ́ \lambda \varepsilon v \sigma i \zeta$

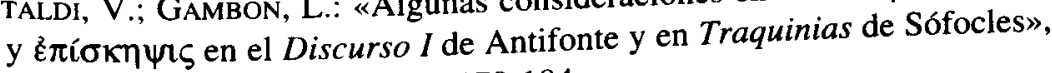
Retórica, política e ideología I 179-184.

RAmírez VIDAL, G.: «Humanismo y cosmopolitismo en Antifonte», Habis 29, 1998, 37-50.

REDONDO, J.: «Retórica y política en los discursos de Antifonte», Retórica, política e ideología I, 165-169.

VARIAS García, C.: «La venjança del pare davant els tribunals en el Contra la madrastra d'Antifont», Faventia 20/2, 1998, 27-31.

\section{Anyte}

Díaz de Cerio DízZ, M.: «La evolución de un género: elementos estructurales de los epigramas dedicados a animales de Ánite de Tegea», Emerita 66, 1998, 149.

DíAz de CERIo DíEZ, M.: «Tipología formal y función estilística de la referencia a la muerte en los epigramas funerarios de Ánite de Tegea», Faventia 20/1, 1998, 49-73.

\section{Apollonius Rhodius}

Fernández Contreras, M.A.: «A.R., 4.123ss.: Motivos tradicionales y “escenas típicas"», SPhV 2, 1997, 23-33. 
Giangrande, G.: «Apolonio de Rodas y las musas apuntadoras», Minerva 12, 1998, 83-89.

Pino CAmpos, L.M.: «Los alados hijos de Bóreas: nota a Apolonio de Rodas, I 219-220", Corolla Complutensis 517-524.

PoCiña, A.: «La nave de la sorpresa: una escena de los Argonautas en Lucio Acio y en Lope de Vega», Actas del IX Congreso VII, 299-303.

\section{Appianus}

Magnino, D.: «Appiano e le proscrizioni triumvirali: un problema di fonti»,

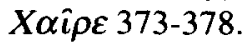

\section{Aratus}

Pereiro, A.: «Tipología de los símiles en los Fenómenos de Arato», Corolla Complutensis 345-350.

\section{Archilochus}

FERNÁNDEZ LóPEZ, M.C.: «Un fragmento de Arquíloco en la Eneida», Actas del IX Congreso V, 72-75.

Gomollón, B.: «La muerte de Arquíloco», $\Delta t \delta a \sigma \sigma \kappa \alpha \lambda o \varsigma$ 55-61.

ZIMMERMANN, B.: «Archiloco, Fr. 120 West, Arione e il ditirambo nel settimo e sesto secolo a.C.», $S P h V 2,1997,63-66$.

\section{Aretaeus}

Areteo de Capadocia: Obra médica. Edición de Miguel E. Pérez Molina. Madrid, Akal, 1998.

\section{Aristaenetus}

ARISTÉNETO: Cartas eróticas. Introducción, traducción y notas de R.J. Gallé Cejudo. Madrid, Ediciones Clásicas, 1998. 


\section{Aristides}

Elio ARístides: Discursos V. Introducciones, traducción y notas de J.M. Cortés Copete. Madrid, Gredos, 1998.

Llera Fueyo, L.A.: «Tres notas al texto del discurso A Capitón de Elio Arístides», Habis 29, 1998, 193-199.

\section{Aristophanes}

ARISTÓfanes: Pluto. Introducción, traducción y notas de L.M. Macía Aparicio. Madrid, Ediciones Clásicas, 1998.

Bravo Garcia, A.: «El Aristófanes de las bibliotecas de la Comunidad de Madrid: una ojeada a los fondos de El Escorial», La comedia griega y su influencia 369-386.

Demont, P.: «Aristófanes el calvo», Actas del IX Congreso IV, 123-128.

GIL, L.: «Aristófanes, Equ. Problemas de hermenéutica y escenificación», Dramaturgia y puesta en escena 221-227.

GIL, L.: «La escenificación de la creatividad intelectual en la comedia aristofánica», Corolla Complutensis 211-218.

Hernández Muñoz, F.; GonZález VÁzquez, C.: «Teatro y metateatro en Las Ranas de Aristófanes», Dramaturgia y puesta en escena 267-272.

LÓPEZ EIRE, A.: «Sóbre el ático coloquial de la Comedia aristofánica», La comedia griega y su influencia 137-175.

LÓPEZ EIRE, A.: «El texto de la comedia aristofánica como texto de una representación dramática», Dramaturgia y puesta en escena 229-250.

LÓPEZ GARCÍA, E.: «Estilos oratorios y reacción del público en la comedia aristofánica», Retórica, política e ideología I, 25-30.

Macía Aparicio, L.M.: «Homero y Aristófanes», Corolla Complutensis 199210.

Martinez Manzano, T.: «Los escolios aristofánicos del Matr.4629 y el humanismo griego del Quattrocento", Corolla Complutensis 579-582.

Mauron, C.: Psicocrítica del género cómico. Aristófanes, Plauto, Terencio, Molière. Madrid, Arco Libros, 1998.

Miranda de Cancela, E.: « ¿Teoría de la comedia en Aristófanes?», SPhV 3, 1998, 37-47.

RIUS, X.: «La consideración de las Asambleístas», Actas del IX Congreso IV, 313-316.

RAMón PALERM, V.: «La lengua literaria de Aristófanes: aspectos didácticos», $\Delta \imath \delta \alpha \sigma \kappa \alpha \lambda \circ \sigma_{\zeta} 63-98$. 
RodRíGUEZ AlfagemE, I: «La forma escénica de la Comedia antigua. Un ejemplo: Los Acarnienses», La comedia griega y su influencia 113-135.

Rodríguez Alfageme, I.: "Lisistrata: estructura escénica», CFCG 8, 1998, 53-73.

RODRÍGUEZ Alfageme, I.: «Aristófanes y la escena», Dramaturgia y puesta en escena 273-287.

Rodríguez Alfageme, I.: "Aristófanes, Aves 755», Corolla Complutensis 219-226.

ThIERCY, P.: «L'évolution de l'action dans les comédies d'Aristophane», $L a$ comedia griega y su influencia 81-100.

ZIMMERMANN, B.: «Aristofane e la crisi dell'educazione ateniese», La comedia griega y su influencia 101-112.

\section{Aristoteles}

Álvarez Gómez, A.; Martínez Castro, R. (eds.): En torno a Aristóteles. Homenaje al profesor Pierre Aubenque. Santiago de Compostela, Universidad, 1998.

ARISTÓTEles: Política. Introducción, traducción y notas de C. García Gual y A. Pérez Jiménez. Madrid, Alianza, 1998.

ARISTÓTELES: Retórica. Introducción, traducción y notas de A. Bernabé. Madrid, Alianza, 1998.

ARIStóteles: Retórica. Poética. Traducción de J. Leita. Barcelona, Península, 1998.

Bellido González, F.J.: «La sistematización de la léxis en Aristóteles y Teofrasto", Retórica, política e ideología 1, 107-113.

CORTÉs GABAUDÁN, F.: «La retórica aristotélica y la oratoria de su tiempo (sobre el ejemplo de Lisias III)", Emerita 66, 1998, 339-359.

JAEgER, W.: Semblanza de Aristóteles. Traducción de J. Gaos. Madrid, Fondo de Cultura Económica de España, 1998.

LÓPEZ EIRE, A.: «Las claves de la Retórica aristotélica», Corolla Complutensis 311-322.

López Grigera, L.: Anotaciones de Quevedo a la Retórica de Aristóteles. Salamanca, s.n., 1998.

Simões Francisco, M.F.: «Aspectos da Verdade na Retórica de Aristóteles», Retórica, política e ideología I, 217-222.

VIANO, C.: «Colère et thumos dans la rhétorique des passions d'Aristote (Rhet.I,10 et II,2)», Retórica, política e ideología I, 101-106. 


\section{Arrianus}

GONZÁlez PONCE, F.J.: «Ideología y literatura en la descripción arrianea del Sudeste Póntico", Actitudes literarias 235-254.

\section{Artemidorus Daldianus}

BarRigón Fuentes, M.C.: «Artemidoro y el mundo del teatro», Actas del IX Congreso IV, 57-63.

\section{Athenaeus}

ATENEO: Banquete de los eruditos. Libros I-II. Introducción, traducción y notas de L. Rodríguez-Noriega Guillén. Madrid, Gredos, 1998.

ATENEO: Banquete de los eruditos. Libros III-V. Introducción, traducción y notas de L. Rodríguez-Noriega Guillén. Madrid, Gredos, 1998.

GómEz, P.: «De actores, cómicos y otros juglares: Ateneo, Banquete de los sofistas XIV 620b-622d», Actas del IX Congreso IV, 163-167.

\section{Basilius Caesariensis}

BAsilio de CESAREA: A los jóvenes. Sobre el provecho de la literatura clásica. Madrid, Gredos, 1998.

\section{Batrachomyomachia}

BALCELls, J.M.: «Consideración de la Batracomiomaquia en tratadistas y poetas españoles áureos», Actas del IX Congreso VII, 55-59.

\section{Biblia Graeca}

ARTÉS HeRnándeZ, J.A.: «¿Griego neotestamentario y traducciones interesadas?», Myrtia 12, 1997, 89-100.

ARTÉs HERnÁndEZ, J.A.: «Evangelios canónicos y Acta Apostolorum Apocrypha: estudio de algunos lugares paralelos», $F N$ 11(21-22), 1998, 25-41. 
BAUMERT, N.: «Ei̧ৎ tó mit Infinitiv», $F N$ 11(21-22), 1998, 7-23.

BiguzzI, G.: «John of Patmos and the "Persecution" in the Apocalypse», EB $56,1998,201-220$.

De WaAl Dryden, J.: «The Sense of $\sigma \pi \varepsilon \rho \mu \alpha$ in 1 John 3:9. In Light of Lexical Evidence», FN 11(21-22), 1998, 85-99.

DERrETT, J.D.M.: «Every "idle" word that men speak (Mt 12,36)», EB 56, 1998, 261-265.

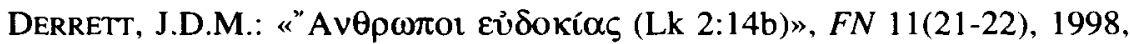
101-106.

FERNÁNDEZ MARCos, N.: Introducción a las versiones griegas de la Biblia. 2." ed. revisada y aumentada. Madrid, Consejo Superior de Investigaciones Científicas, 1998.

FITZMYER, J.A.: «Alonso Schökel and $\Delta 1 \kappa \alpha \iota \circ \sigma u ́ v \eta$ $\theta \varepsilon 0 \hat{», ~} E B$ 56, 1998, 107109.

FUENTE ADÁNEZ, A. DE LA: «Trasfondo cultural del cuarto evangelio: sobre el ocaso del dilema judaísmo/gnosticismo», EB 56, 1998, 491-506.

GARCÍA DE LA FuENTE, O.: «Abyssos y abyssus en la Biblia griega y latina», Actas del IX Congreso $\mathrm{V}, 87-91$.

GIL, L.: «Las curaciones del Nuevo Testamento», CFCG 8, 1998, 9-42.

Gnilka, J.: Pablo de Tarso. Apóstol y testigo. Barcelona, Herder, 1998.

GUIJARRO OPORTO, S.: «Reino y familia en conflicto: una aportación al estudio del Jesús histórico», $E B$ 56, 1998, 507-541.

LEE, J.A.L.; HoRSLEY, G.H.R.: «A Lexicon of the New Testament with Documentary Parallels: Some Interim Entries. 2», FN 11(21-22), 1998, 57-83.

LOPEZ FERNÁNDEZ, E.: El mundo joánico. Introducción al cuarto evangelio. Oviedo, s.n., 1998.

Makujina, J.: «Verbs meaning "command" in the New Testament: determining the factors involved in the choice of command-verbs", $E B 56$, 1998, 357-369.

Makujina, J.: «Modal Possibilities for the Elliptical Verb in the ImperativeComparative Clause in NT Greek», $F N$ 11(21-22), 1998, 43-55.

Martorell, E.: El griego del Nuevo Testamento. Tarrasa, Clíe, 1998.

Moreno García, A.; Limburg, K.: «Comentario a Mat 10,16 de Pedro de Valencia. Un manuscrito inédito de la Biblioteca Nacional de Madrid», $\mathrm{Hel}$ mantica 49, 1998, 247-266.

Ollero Granados, D.: «La teoría del “aspecto" y In 20,17a», CFCL 15, 1998, 313-321.

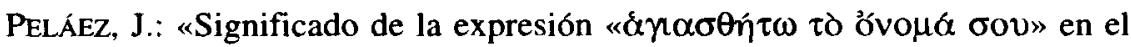
evangelio de Mateo (6,9)», CFCG 8, 1998, 43-52.

Pertini, M.A.: «La genialidad gramatical de Jn 8,25», EB 56, 1998, 371-404. 
Pikaza, X.: Pan, casa, palabra. La iglesia en Marcos. Salamanca, Sígueme, 1998.

Raimbault, C.: «Una analyse structurelle de l'adoration des Mages en Mt 2,1$12 », E B$ 56, 1998, 221-235.

Rius CAMPS, J.: «Las variantes de la Recensión occidental de los Hechos de los Apóstoles (X)», FN 11(21-22), 1998, 107-122.

Rodríguez Ruiz, M.: «Estructura del evangelio de San Juan desde el punto de vista cristológico y eclesiológico», $E B$ 56, 1998, 74-96.

TAssin, C.: «Des versions bibliques anciennes à leus artisans: Targum, Septante et Nouveau Testament", EB 56, 1998, 315-334.

VICENT CERnUDA, A.: «De la hostilidad galilea a la conjura final contra Jesús», $E B$ 56, 1998, 465-490.

Vocabulario GRIEGo del NuEvo TeSTAMENTo. Salamanca, Sígueme, 1998.

\section{Bio}

Prieto Pérez, S.: «iHa muerto el bello Adonis! Bión entre bastidores», Actas del IX Congreso IV, 295-300.

\section{Callimachus}

Calderón Dorda, E.: «Observaciones a Calímaco. A.P. XII 150», Corolla Complutensis 249-254.

Giangrande, G.: «On Callimachus' Literary View Concerning Epic», Veleia 15, 1998, 389.

González Galván, M.G.: «La mujer en Calímaco», Actas del IX Congreso VI, 109-112.

VALVERDE, M.: «El léxico musical en Calímaco», Corolla Complutensis 369376.

Cebes

Ruiz Gito, J.M.: «La traducción del Maestro Gaspar Hernández, un manuscrito desconocido en la tradición de La Tabla de Cebes en España», Actas del IX Congreso VII, 338-344. 


\section{Chrysostomus, Iohannes}

GonzÁlez Blanco, A.: «La magia en los siglos IV-V a la luz de las obras de

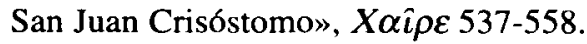

HiLl, R.C.: «Chrysostom, interpreter of the Psalms», EB 56, 1998, 61-74.

\section{Clemens Alexandrinus}

Clemente de Alejandría: El pedagogo. Traducción de J. Sariol Díaz. Madrid, Gredos, 1998.

\section{Cratinus}

Amado Rodríguez, M.T.: «Expresiones proverbiales en los fragmentos de Cratino", Actas del IX Congreso IV, 49-55.

\section{Ctesias}

Lens Tuero, J.: «Comedia e Historiografia: Ctesias de Cnido», La comedia griega y su influencia 271-306.

\section{Cyrillus Alexandrinus}

Cirilo, Santo, Patriarca de Alejandría: ¿Por qué Cristo es uno? Introducción y notas de L. Leone. Traducción del griego de S. García-Jalon, Madrid, Ciudad Nueva, 1998.

\section{Demosthenes}

CARLIER, P.: «A propósito de Queronea», EClás.114, 1998, 41-52.

Demóstenes: Las Filípicas. Sobre la corona. Edición de A. López Eire. Madrid, Cátedra, 1998.

García RuIZ, M.: «El empleo de sentencias en los Discursos II y III de Esquines y XVIII y XIX de Demóstenes», Corolla Complutensis 305-310. 


\section{Dio Cassius}

ESCRIBANO, M.V.: «Pensamiento político y expresión historiográfica en Casio

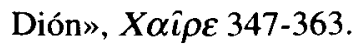

\section{Dio Chrysostomus}

Hidalgo de la Vega, M.J.: «El Boristénico de Dión de Prusa y la ciudad platónica», $X \alpha \hat{\imath} \rho \varepsilon$ 421-430.

\section{Diodorus Siculus}

Ambaglio, D.: «Diodoro de Sicilia y la tradición histórica fragmentaria»,

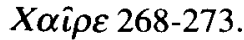

AlONSO NúÑEZ, J.M.: «Diodoro sobre las minas en Hispania y el estoicismo (Bibliotheca Historica, V, 35-38)», MHA 17, 1996, 175-178.

Camacho Rojo, J.M.; Fuentes González, P.P.; López Cruces, J.L.: «Las citas en Diodoro de Sicilia I. Las citas poéticas», Fortunatae 9, 1997, 13-32. Chávez Reino, A.L.: "Diodoro y la historiografía griega», Actitudes literarias 255-281.

VELASCO LÓPEZ, M.H.: «Diodoro V 28.5-6 y la creencia del alma entre los celtas», Actas del IX Congreso VI, 249-254.

\section{Diogenes Laertius}

Gallé Cejudo, R.J.: «Una glosa afortunada. A propósito de D.L. VIII 65», Actas del IX Congreso IV, 151-156.

\section{Pseudo Dionysius Areopagita}

Cavallero, P.A.: «Las Escrituras y el Logos en Los nombres divinos del Pseudo-Dionisio», EB 56, 1998, 96-105.

\section{Dionysius Halicarnassensis}

Fernández Contreras, M.A.: «Aspectos de la propaganda en la Arqueología Romana de Dionisio de Halicarnaso», Actitudes literarias 209-234. 
SÁNCHEZ JiMÉNEZ, F.: «Algunos aspectos de la versión más antigua conservada sobre la destrucción de Troya», X $\alpha \hat{\imath} \rho \varepsilon$ 115-125.

\section{Dioscorides}

DIOSCÓRIDES: Plantas y remedios medicinales (De materia medica). Libros IIII. Introducción, traducción y notas de Manuela García Valdés. Madrid, Gredos, 1998.

DIOSCÓRIDES: Plantas y remedios medicinales (De materia medica). Libros IV$V$. Traducción y notas de Manuela García Valdés. Madrid, Gredos, 1998. García JuRado, F.: «Antiguos textos de ciencia convertidos en poesía: Dioscórides y Andrés de Laguna en el Libro de los venenos de Antonio Gamoneda», Epos 13, 1997, 379-395.

Martínez Manzano, T.: «El Salm.2659 de Dioscórides y la historia del fondo griego de la Biblioteca Universitaria de Salamanca procedente del Colegio de San Bartolomé», Helmantica 49, 1998, 309-328.

\section{Elegiaca Alexandrina adespota}

Giangrande, G.: «Artemis, the Calydonian Boar and Papyri», Habis 29, 1998, 69-76.

\section{Epicharmus}

BenAvente, M.: «Una metáfora común a Epicarmo, Lorca y Kipling», Corolla Complutensis 751-754.

\section{Epicurus}

EPICuRo: Carpe diem. Traducción de H. Etxeberría. Legutiano, Infomart, 1998. MEdina GonZÁLEZ, A.: «Placer, naturaleza y autarquía en la ética epicúrea», Corolla Complutensis 433-438.

Otón Sobrino, E.: «La ortodoxia del discípulo», Corolla Complutensis 439442. 


\section{Eratosthenes}

Pàmias I Massana, J.: «Sobre el fragment dels Catasterisms d'Eratòstenes del manuscrit Parisinus Graecus 1310: el nom dels planetes Saturn i Júpitern, Faventia 20/2, 1998, 71-77.

\section{Eroticorum Fragmenta Papyracea}

LÓPEZ MARTínez, M.P.: «Las otras novelas griegas», Actas del IX Congreso IV, 207-212.

LÓPEZ MARTÍNEZ, M.P.: «La paideia del príncipe Nino», Retórica, política e ideología I, 51-56.

LÓPEZ MARTÍNEZ, M.P.: Fragmentos papiráceos de novela griega. Alicante, Universidad, 1998.

\section{Eumelus}

MARTínez Nieto, R.B.: «Deformación mítica y fines políticos en Eumelo de Corinto», Retórica, política e ideología I, 133-140.

\section{Eupolemus}

Nieto IbáÑez, J.M.: «La mitología universal del Pseudo-Eupólemo (Eus.PE IX 18,2)», Corolla Complutensis 525-530.

\section{Euripides}

Almirall SARDÁ, J.: «EL miedo de Héctor a las estrellas (Eur., El.452s.)», Actas del IX Congreso IV, 41-44.

CAPONE CIOllaro, M.: «Il dialogo a tre in Euripide», Dramaturgia y puesta en escena 39-52.

Clavo, M.T.: «Una parodia del simposio en el Cíclope de Eurípides», Actas del IX Congreso IV, 107-110.

Esteban Santos, A.: «Composición axial en Eurípides: en torno a la mujer y la muerte», Dramaturgia y puesta en escena 99-119.

EuRf́PIDES: Andrómaca. Traducción de J.L. Navarro. Madrid, Ediciones Clásicas, 1998. 
EuRíPIDEs: Electra. Traducción de Carmen Vilela. Madrid, Ediciones Clásicas, 1998.

EurípIDEs: Ifigenia en Táuride. Traducción de A. Martínez Díez. Madrid, Ediciones Clásicas, 1998.

EURíPIDES: Las fenicias. Traducción de J.M. García López. Madrid, Ediciones Clásicas, 1998.

GonZÁles de Tobía, A.M.: "Heracles de Eurípides. Una interpretación», Actas del IX Congreso IV, 169-178.

LÓPEZ FÉrEZ, J.A.: «Notas de técnica dramatúrgica euripidea. Lo cotidiano en Alcestis», Dramaturgia y puesta en escena 177-191.

MARIÑo, R.M.: «Diez $\kappa \hat{\omega} \lambda \alpha$ yámbicos en Eurípides», Corolla Complutensis 383-388.

QuiJADA, M.: «Ifigenia en Áulide y la tragedia tardía de Eurípides», Actas del IX Congreso IV, 307-312.

Rodríguez AdRADOs, F.: «Volvamos al léxico y la sintaxis de los manuscritos. A propósito de Eurípides, Medea y Cíclope», Actas del IX Congreso IV, 317-322.

\section{Eusebius Caesariensis}

NiETo IbáÑez, J.M.: «La mitología universal del Pseudo-Eupólemo (Eus.PE IX 18,2)», Corolla Complutensis 525-530.

\section{Gorgias}

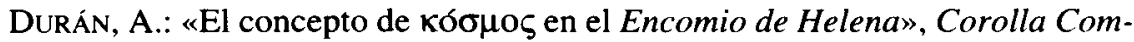
plutensis 179-186.

MESTRE, F.: Gorgias, la concordia, los muertos y la palabra", Actas del IX Congreso IV, 245-249.

\section{Gregorius Nyssenus}

Bravo García, A.: «El rechazo del mundo en la literatura griega cristiana del s. IV y sus implicaciones filosóficas», Actas del IX Congreso IV, 81-85.

\section{Hellanicus}

SÁNCHEZ JIMÉNEZ, F.: «Algunos aspectos de la versión más antigua conserva-

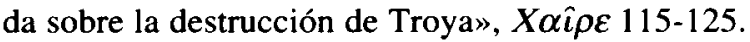




\section{Herennius Philo Byblius}

Maldonado Villena, F.: «La Teogonía de Sanchuniathon, ¿Mito o realidad?», Religión, magia y mitología 123-135.

Mendes Moreira, A.M.: «A interpretatio graeca de Kothar/Khusor em Fílon de Biblos", Retórica, política e ideología I 329-335.

\section{Hermogenes rhetor}

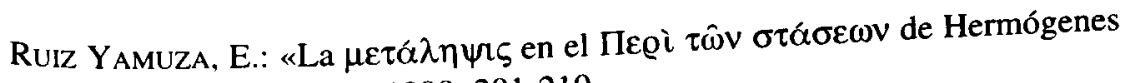
de Tarso», Habis 29, 1998, 201-210.

\section{Herodas}

Llera Fueyo, L.A.: «Teofrasto y Herodas», Minerva 12, 1998, 91-102.

\section{Herodotus}

Alemany I VILAMAJó, A.: «L'expedició dels khàzars: un paral.lel caucàsic d'Heròdot?», Faventia 20/2, 1998, 45-59.

GonzÁlez Almenara, G.: «Algunas consideraciones sobre el papel de las esposas en las Historias de Heródoto y Tucídides», Actas del IX Congreso VI, 105-108.

\section{Hesiodus}

Aguirre, M.: «Fórmulas y expresiones genealógicas en la Teogonía: las descendencias de Noche y Gea», Corolla Complutensis 461-468.

PAPARIzos, A.: «Modes de pensée chez Hésiode et négation de l'autorité absolue», Minerva 12, 1998, 17-39.

SÁnchez ORTIZ de LANDAluCE, M.: «El mito de Pandora en Hesíodo: un nuevo análisis interpretativo de un relato esperanzador», Minerva 12, 1998, 41-52.

\section{Hippocrates et Corpus Hippocraticum}

ESTEBAN, A.: «Esquema composicional de las historias clínicas de Epid.V y VII. Encabezamiento: Quién, Dónde y Cuándo», Corolla Complutensis 415-422. 
LARA, D.: «El capítulo 24 del De vetere medicina hipocrático: un ejemplo de método», Corolla Complutensis 405-410.

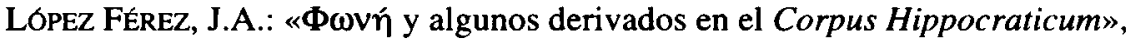
Corolla Complutensis 423-432.

\section{Homerus}

Aguilar Sanchís, M.: "La cólera de Meleagro como "puesta en abismo" de la cólera de Aquiles (Il.IX 524-599)", Actas del IX Congreso IV, 29-35.

Alesso, M.; GonZÁlez, A.: «Euriclea o la construcción de un personaje emblemático», Actas del IX Congreso IV, 35-40.

ARTERO, A. ET AlII: Odisea 6. Texto, comentarios y traducción. Almería, Consejería de Educación y Ciencia de la Junta de Andalucía, 1998.

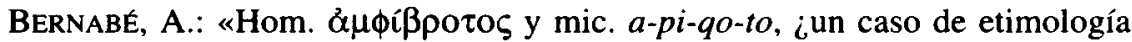
popular?», Corolla Complutensis 39-48.

BONED COleRA, P.: «La descripción de un jardín: motivo poético en Nonno y Homero", Actas del IX Congreso IV, 77-80.

Buenosvinos, Á.: «Los escolios $D$ del manuscrito $\Omega-1-12$ del Escorial», Emerita 66, 1998, 391-397.

Closa FaRRÉs, J.: «Winckelmann y la lectura artística de Homero», $\Delta ı \delta \alpha ́ \sigma \kappa \alpha \lambda \circ \varsigma$ 279-289.

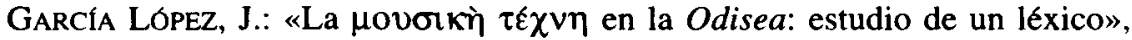
Corolla Complutensis 363-368.

Homero: Ilíada. Vol. II: Cantos IV-IX. Texto, traducción y notas por J. García Blanco y L.M. Macía Aparicio. Madrid, Consejo Superior de Investigaciones Científicas, 1998.

Homero: La llíada. Madrid, Club Internacional del Libro, 1998.

Homero: La llíada. Prólogo y notas de J. Alarcón Benito. Ilustraciones de J.J. Aguilar. Madrid, Edimat, 1998.

Homero: La llíada o El sitio de Troya. Presentación de L.A. de Cuenca. Prologo de J. García Padrino. Versión de M.L. Morales. Madrid, Anaya, 1998.

Homero: La Odisea. Presentación de L.A. de Cuenca. Madrid, Anaya, 1998.

Homero: Odisea. Prólogo y notas de J. Alarcón Benito. Madrid, Edimat, 1998. Homero: Odisea. Traducción de L. Segalá y Estalella. Barcelona, Península, 1998.

MaCía Aparicio, L.M.: «Lista de papiros para una edición de la Ilíada», Tempus 20, 1998, 5-57.

MACÍA APARICIO, L.M.: «Homero y Aristófanes», Corolla Complutensis 199-210. 
Morenilla Talens, C.: «Aquiles, héroe a su pesar», SPhV 2, 1997, 35-47.

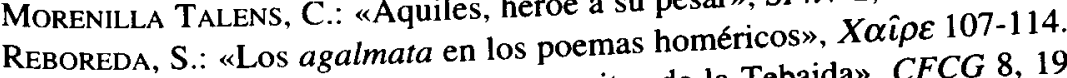

TORRES-GuERrA, J.B.: «Homero, compositor de la Tebaida», CFCG 8, 1998, 133-145.

VILla POlO, J. DE LA: «La agentividad en la lengua homérica», Nombres y funciones 147-180.

\section{Hymni Homerici}

Fernández Delgado, J.A.: «Las proteicas vacas del Himno a Hermes: dicción formular y parodia», Emerita 66, 1998, 1-14.

Hoz, M.P. D: «Los Himnos Homéricos cortos y las plegarias cultuales», Emerita $66,1998,49-66$.

\section{Ibycus}

Torres Guerra, J.B.: «Rubia Helena (Íbico, S 151 PMGF, v. 5)», Minerva 12, $1998,53.56$.

\section{Iosephus}

BEGG, C.: «David's double victory according to Josephus», Emerita 66, 1998, 27-48.

IBARRA BENLLOCH, M.: «Un caso de antropofagia: María, hija de Eleazar (I.BI VI 201-213 apud Eus.HE III 6-20-28)», Actas del IX Congreso VI, 147-151.

SiMÕes RodrIGUES, N.: «Jefte e Jónatas no palco. $O$ trágico como retórica historiográfica em Josefo", Retórica, política e ideología Il, 347-353.

\section{Isocrates}

MARÍn VALDÉs, F.A.: «Retórica y promoción monumental: Isócrates y Pericles benefactor», Retórica, política e ideología I, 153-158.

Pérez-Castilla Álvarez, J.: «Isócrates y el pacifismo realista», Actas del IX Congreso IV, 281-284.

Signes CODOÑER, J.: «El Panatenaico de Isócrates: 2 . Tema y finalidad del discurso», Emerita 66, 1998, 67-94. 


\section{Leonidas epigrammaticus}

WhITE, H.: «Leonidas and Love», Myrtia 12, 1997, 87-88.

\section{Longinus}

Morenilla Talens, C.: «Los textos a través de los textos: Esquilo en el De sublimitate", Actas del IX Congreso IV, 259-263.

\section{Longus}

LoNGO: Dafnis y Cloe. Traducción de J. Valera. Barcelona, Edicomunicación, 1998.

FERnÁNDEZ GaRCIA, A.J.: "Las perífrasis de infinitivo en el Dafnis y Cloe de Longo", Fortunatae 9, 1997, 33-39.

Prieto Prieto, M.L.: «Papel de los animales en la novela de Longo», Actas del IX Congreso IV, 301-305.

\section{Lucianus}

García Teijeiro, M.: "Luciano XLII 7 y las culebras que maman», Actas del IX Congreso IV, 157-161.

GuzMÁn Guerra, A.: «Francisco de la Reguera, traductor de los Relatos Veridicos de Luciano. Un manuscrito inédito de la BN", Actas del IX Congreso VII, 163-167.

Luciano de Samosata: Relatos fantásticos. Introducción de C. García Gual. Madrid, Alianza, 1998.

\section{Lycophro}

GIANGRANDE, G.: «Sobre un papiro de Licofrón», Veleia 15, 1998, 385-387.

\section{Lysias}

CORTÉs GABAUdÁN, F.: «La retórica aristotélica y la oratoria de su tiempo (sobre el ejemplo de Lisias III)», Emerita 66, 1998, 339-359. 


\section{Menander}

LAMAgna, M.: «Dialogo riportato in Menandro», Dramaturgia y puesta en escena 289-302.

Morenilla TAlens, C.: «El hetairos en Menandro», La comedia griega y su influencia 227-269.

Perusino, F.: «Menandro e il simposio: nota al P.Oxy. 3705», CFCG 8, 1998, 103-108.

PociÑA, A.:»Menandro en la comedia latina», La comedia griega y su influencia 345-367.

\section{Menander rhetor}

PONCE, M.J.: «Hacia una valoración histórica de los tratados atribuidos a Menandro rétor», X $\alpha \hat{\imath} \rho \varepsilon$ 411-419.

Ponce, M.J.: «Menandro rétor y el discurso imperial», Habis 29, 1998, 221232.

\section{Nicander Colophonius}

TOUWAIDE, A.: «Nouvelles perspectives pour l'édition et la lexicologie des poèmes de Nicandre», Emerita 151-178.

\section{Nonnus}

Boned Colera, P.: «La descripción de un jardín: motivo poético en Nonno y Homero", Actas del IX Congreso IV, 77-80.

Villarrubia, A.: «Nono de Panópolis y el mito de Acteón», Habis 29, 1998, 249-268.

\section{Oppianus Apamensis}

Martín García, F.: «Las cesuras en los hexámetros de los Cinegética de Opiano», Corolla Complutensis 389-396. 


\section{Orphica}

BERNABE, A.: «La noche en las Rapsodias órficas», Actas del IX Congreso IV, 71-76.

\section{Pausanias}

Tsirkin, J.B.: «Nórax, hijo de Eritea», Polis 9, 1997, 277-283.

\section{Philo Iudaeus}

Gillabert BarberÀ, P.: «Dios (Yahvé) es platónico, o cómo el judaísmo alejandrino (Filón, De opificio mundi) adopta y adapta el patrimonio filosófico griego», Actas del IX Congreso VII, 129-132.

Rodríguez MoREno, I.: «La demonología y la angelología en los inicios del imperio. Filón de Alejandría», Helmantica 49, 1998, 267-284.

\section{Philostratus}

MESTRE, F.: Gorgias, la concordia, los muertos y la palabra», Actas del IX Congreso IV, 245-249.

Signes Codoñer, J.: «åvar Tiana 5.38)», Minerva 12, 1998, 103-108.

\section{Philostratus Maior}

ElvirA, M.A.: «La iconografía del poeta en las imagines filostrateas», X $\alpha \hat{i} \rho \varepsilon$ 431-441.

Phrynichus atticista

Barbeito, P.: «Pedro Juan Núñez, editor de Frínico», Corolla Complutensis 655-665. 


\section{Phrynichus tragicus}

MARCOVICH, M.: «Frínico o la primera etapa de la tragedia griega», Actas del IX Congreso IV, 219-224.

\section{Pindarus}

CRISTÓbal, V.: «Píndaro y Horacio: a propósito de la Ístmica VII», Corolla Complutensis 273-280.

Herrera Montero, R.: «Tríptico: Safo (1 P.), Sófocles (E.R.1186-1222), Píndaro (Ol.XIV) en doble versión poética», Corolla Complutensis 127-130.

SCHMID, M.J.: «Speaking personae in Pindar's Epinikia», CFCG 8, 1998, 147-184.

SCHMID, M.J.: «Skytála Moisân: Song and writing in Pindar», Minerva 12, 1998, 57-81.

\section{Plato}

ARANA, J.R.: «El Ión, fundador de la hermenéutica occidental», Veleia 15, 1998, 257-276.

CAPPelletti, G.: «Le suggestioni di Platone: fascino e seduzione del dialogo», Retórica, política e ideología I, 199-204.

Díaz de Cerio Díez, M.; Serrano Cantarín, R.: «El ataque a la retórica como $\tau \varepsilon \chi \chi \vee \eta$ en el Gorgias de Platón», Retórica, política e ideología I, 209 215.

FORES, L.: «Retórica y utopismo político: el caso Platón», Retórica, política e ideología I, 205-208.

Macua Martínez, E.: «Teatro y poder político-social en la antigua Grecia: la censura platónica de la tragedia», Veleia 15, 1998, 277-285.

Martínez, M.; Pino Campos, L.M.; Santana Henríquez, G.: Los mitos de Platón. Antología de Textos. Santa Cruz de Tenerife, Consejería de Educación, 1998.

Martínez Benavides, M.J.: "La filosofía de Platón en el Renacimiento a través de un intermediario», Fortunatae 9, 1997, 81-101.

Moreno Hernández, A.: «Séneca, Ep.LVIII y las traducciones latinas del léxico filos6́fico platónico", Actas del IX Congreso III, 191-198.

Navarro, M.: «De la casa de Agatón a La montaña mágica», Actas del IX Congreso VII, 269-274. 
Plató: El banquet. Fedre. Traducció de J. Leita. Barcelona, Península, 1998.

Platón: Diálogos. Traducción de J. Bergua. Madrid, Alba, 1998.

Platón: Diálogos. Gorgias o de la Retórica, Fedón o de la inmortalidad, El Banquete o el amor. Introducción de C. García Gual. Madrid, Espasa Calpe, 1998.

Platón: Fedón. Fedro. Introducción, traducción y notas de L. Gil Fernández. Madrid, Alianza, 1998.

Platón: Mitos. Prólogo de C. García Gual. Traducción de C. García Gual, J. Calonge, E. Lledó y otros. Selección y actividades por F. García Moriyón. Madrid, Siruela, 1998.

Platón: Protágoras. Gorgias. Carta Séptima. Introducción, traducción y notas de F.. Martínez García. Madrid, Alianza, 1998.

ROSETTI, L.: «Il mito escatologico in Platone e il suo dubbio statuto epistemico», Religión, magia y mitología 265-282.

Ruiz Montero, C.: «Precisiones terminológicas a Platón, R.392c-400d», Corolla Complutensis 443-446.

Ruiz YamuZa, E.: «Los dos primeros discursos del Fedro de Platón: topoi homoeróticos», Corolla Complutensis 447-459.

SChIAPPA DE AZEVEdo, M.T:: «Retórica filosófica feminina em Platão: Aspásia e Diotima», Retórica, política e ideología I, 223-228.

Tudela SANCho, A.: «Lenguaje, retórica y política en aporía. La escritura como fármacon en el Fedro de Platón», Retórica, política e ideología I. 193198.

\section{Plotinus}

Plotino: Enéadas V-VI. Introducciones, traducciones y notas de Jesús Igal. Madrid, Gredos, 1998.

\section{Plutarchus}

Agullar, R.M.: «Tucídides en Plutarco», Corolla Complutensis 255-262.

Caballero SÁnchez, R.: «El Amatorius de Plutarco y la locura amorosa», Actas del IX Congreso IV, 95-100.

Durán Mateu, M.: «Las Cuestiones de mesa de Plutarco: ¿en la base de los Deipnosofistas de Ateneo?», Actas del IX Congreso IV, 139-144. 
Martínez Manzano, T.: «Dos traducciones renacentistas de Plutarco inéditas», Actas del IX Congreso VII, 223-228.

Martos Montiel, J.F.: «Argumentos cirenaicos en la crítica plutarquea de la doctrina epicúrea», Actas del IX Congreso IV, 235-237.

Morales Ortiz, A.: «Pedro Juan Núñez, traductor de Plutarco», Actas del IX Congreso VII, 253-257.

Navarro, M.: «De la casa de Agatón a La montaña mágica», Actas del IX Congreso VII, 269-274.

Pérez Jiménez, A.: «Ciencia, religión y literatura en el Mito de Sila de Plutarco», Actitudes literarias 283-294.

Plutarco: Vida de Alejandro. Madrid, Fondo de Cultura Económica, 1998.

Plutarco: Vidas Paralelas. Alcibíades-Coriolano. Sertorio-Eumenes. Introducción de A. Bravo García. Traducción y notas de M.A. Ozaeta Gálvez. Madrid, Alianza, 1998.

PlutarCo: Vidas paralelas. Madrid, Club Internacional del Libro, 1998.

Ramón PAlerm, V. (ed.): Plutarco de Queronea. Bibliografía española. Madrid, Ediciones Clásicas, 1998.

Ruiz LóPEZ, D.: «Mujeres licias (Plut.Mul.Virt.9.248D)», Actas del IX Congreso VI, 219-224.

\section{Pollux}

MACUA, E.: «Pólux, Onomasticon 143-154: traducción e interpretación del posible sentido del catálogo de máscaras de la Nea», Corolla Complutensis 239-242.

\section{Polybius}

Díaz Tejera, A.: «Polibio 3,24,1, El segundo tratado entre Roma y Cartago.

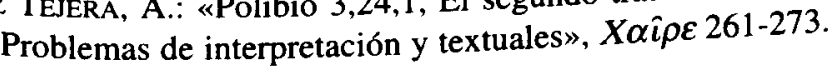

\section{Procopius Caesariensis}

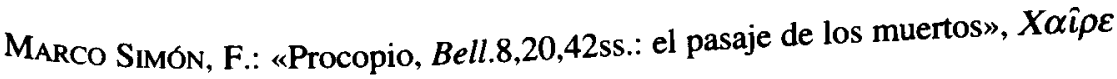
497-511. 


\section{Ptolemaeus}

Gómez Fralle, J.M.: «Elementos políticos en la conformación geográfica de la Hispania citerior en Claudio Ptolomeo», Retórica, política e ideología I, 319-326.

\section{Pythagoras et Pythagorici}

Pino Campos, L.M.: «Proverbios pitagóricos», Actas del IX Congreso IV, 285288.

\section{Quintus Smyrnaeus}

Calero Secall, I.: «El Áyax de Quinto de Esmirna y sus precedentes literarios», Actitudes literarias 77-91.

Calero SeCall, I.: «La figura de Neoptólemo en la epopeya de Quinto de Esmirna», Actas del IX Congreso IV, 101-106.

Fernández Contreras, M.A.: «La animación del entorno en los Posthomérica de Quinto de Esmirna», Habis 29, 1998, 233-247.

\section{Rhianus}

Clúa Serena, J.A.: «Los fragmentos de Riano. Status quaestionis», Actas del IX Congreso IV, 111-115.

\section{Rufinus}

WhITE, H.: «Two Obscene Epigrams by Rufinus», Veleia 15, 1998, 393-396.

\section{Sappho}

GuZMÁn Guerra, A.: «Motivaciones de las conexiones metafóricas "oír/cumplir un deseo" ( $\kappa \lambda \cup \omega \omega)$ en Safo», Corolla Complutensis 127-130.

HerRera Montero, R.: «Tríptico: Safo (1 P.), Sófocles (E.R.1186-1222), Píndaro (Ol.XIV) en doble versión poética», Corolla Complutensis 127-130. 
ROdRIGUEz SOMOLinos, H.: El léxico de los poetas lesbios. Diccionario Griego Español, Anejo IV. Madrid, Consejo Superior de Investigaciones Científicas, 1998.

Safo: Poemas y fragmentos. Traducción de J.M. Rodríguez Tobal. Madrid, Grijalbo-Mondadori, 1998.

\section{Simonides}

BARRIGón, C.: «Observaciones sobre Sim.fr.22 West», Corolla Complutensis 139-146.

Solo

LEĀO, D.: «Sólon e a guerra por Salamina», Retórica, política e ideología I, 141-146.

TORnÉ TeIXIDÓ, R.: «Solón y el catálogo de los afanes humanos (Elegía a las Musas, vv.43-62)», Actas del IX Congreso IV, 329-333.

\section{Sophocles}

ÁNGEL ESPINÓs, J.: «Lo invisible como recurso escénico en el fragmento 269c Radt de Ínaco de Sófocles», Dramaturgia y puesta en escena 167-176.

DOUTERELO FERNÁNDEZ, E.: «La salida en silencio de Deyanira en Las Traquinias de Sófocles», Actas del IX Congreso IV, 133-137.

FORTE, N.B.: «Transpolación de la materia mítica épica a la tragedia», Actas del IX Congreso IV, 145-150.

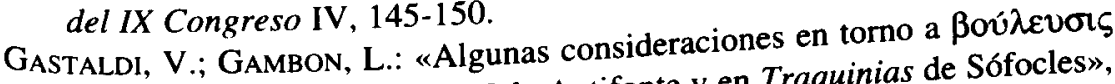
y દ̇́íormurç en el Discurso I de Antifonte y en Traquinias de Sófocles», Retórica, política e ideología I 179-184.

Herrera Montero, R.: «Tríptico: Safo (1 P.), Sófocles (E.R.1186-1222), Píndaro (Ol.XIV) en doble versión poética», Corolla Complutensis 127-130.

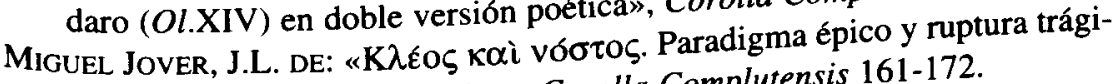
ca en el Filoctetes de Sófocles», Corolla Complutensis 161-172.

PABÓN DE ACUÑA, C.T.: «Ě̌ $\kappa \omega$ en Sófocles: la intransigencia del héroe», Corolla Complutensis 173-178.

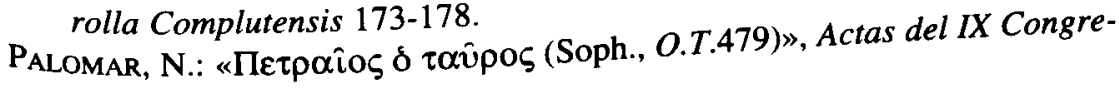
so IV, 271-275. 
REDONDO, J.: «Per a una diacronia de la llengua literària de Sòfocles», SPhV 2 , 1997, 49-61.

SCABuzzo, S.: «EI discurso del poder en Antígona de Sófocles», Retórica, política e ideología 1, 171-177.

SófOCles: Electra. Traducción de J.M. Rodríguez. Madrid, Alba, 1998.

Sófocles: Memoria de Antigona. Adaptación de F. Cadaval Ayuso y X. Lama. Santiago de Compostela, Junta de Galicia - Instituto Galego das Artes Escénicas e Musicáis, 1998.

\section{Stesichorus}

Gangutia Elícegui, E.: «Gerioneidas. Desarrollo literario griego en contacto con el Próximo Oriente», Emerita 66, 1998, 231-256.

\section{Strabo}

Saquete Chamizo, J.C.: «L. Antonio L.F. Quir. Vegeto Turdulo y Estrabón 3.1.6. Sobre la romanización en la Baeturia Turdula», Habis 29, 1998, 117-128.

\section{Suda uel Suidas}

RuIz DE ElvirA, A.: «Suidas, y no La Suda», Myrtia 12, 1997, 5-8.

\section{Thebaïs}

Torres-Guerra, J.B.: «Homero, compositor de la Tebaida», CFCG 8, 1998, 133-145.

\section{Themistocles}

Pérez Jiménez, A.: «Grandeza retórica de un exiliado: los diálogos de la Carta veinte de Temístocles», Corolla Complutensis 351-361. 


\section{Theo}

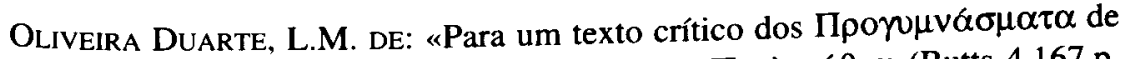
Élio Téon; leitura de um passo do capítulo Пepì $\mu u ̛$ oov (Butts 4.167,p. 276 = Spengel 78.9)», Habis 29, 1998, 211-220.

\section{Theocritus}

Brioso SÁnCHEZ, M.: «De nuevo sobre los orígenes de la poesía bucólica: ¿Te-

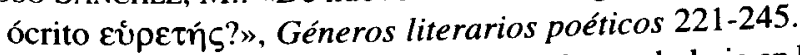

CASTRO DE CASTRO, J.D.: «Algunos aspectos de vocabulario en la traducción de los Idilios de Teócrito de Vicente Mariner», Actas del IX Congreso VII, 89-93.

Cavallero, P.A.: «Dos propuestas de crítica textual sobre el Idilio II de Teócrito (vv. 61 y 164)», Emerita 66, 1998, 307-319.

Molinos Tejada, T.: «Lengua y estilo en el Idilio XIII de Teócrito», Corolla Complutensis 329-334.

\section{Theophrastus}

Bellido González, F.J.: «La sistematización de la léxis en Aristóteles y Teofrasto», Retórica, política e ideología I, 107-113.

LleRA FueYo, L.A.: «Teofrasto y Herodas», Minerva 12, 1998, 91-102.

\section{Thucydides}

Agullar, R.M.: «Tucídides en Plutarco», Corolla Complutensis 255-262.

FORNIS, C.: «La actualidad del debate tucidídeo», Gerión 16, 1998, 483-492.

GonzÁlez Almenara, G.: «Algunas consideraciones sobre el papel de las esposas en las Historias de Heródoto y Tucídides», Actas del IX Congreso VI, 105-108.

IGLESIAS ZOIDO, J.C.: «Algunas consideraciones con respecto al empleo del $\pi \alpha \dot{\theta}$ os en la argumentación de los discursos de Tucídides», Actas del IX Congreso IV, 197-202.

IGLESIAS ZOIDO, J.C.: «Las arengas de Tucídides y el problema de su adscripción a un género oratorio", Retórica, política e ideología I, 65-59.

Miguel Jover, J.L. DE: «Retórica, ritual y comunicación en el Discurso fúnebre de Pericles (Tuc.II, 34-46)», Retórica, política e ideología I, 159-163. 


\section{Xenophanes}

TORRES GUERRA, J.B.: «El estilo de Jenófanes», Actas del IX Congreso IV, 335-340.

\section{Xenopho}

Caballero López, J.A.: «La República de los Atenienses del Viejo Oligarca como ensayo", Actas del IX Congreso IV, 87-93.

GonZÁlez CASTRO, J.F.: «El exilio de Jenofonte»: Gerión 16, 1998, 177-181.

Vela TejadA, J.: Post H.R. Breitenbach: tres décadas de estudios sobre Jenofonte (1967-1997). Actualización científica y bibliográfica. Zaragoza, Universidad, 1998.

\section{Xenopho Ephesius}

LuCAS DE Dios, J.M.: «Jenofonte de Éfeso: estructura del relato», Actas del IX Congreso IV, 213-218.

\section{Historia DE LA LITERATURA}

ALEXANDRE JÚNIOR, M.: «Narração e cria na historiografia antiga», Retórica, política e ideología I, 57-63.

ANDREWS, J.A.: «Audience and Ideology in Democratic Athens», Retórica, política e ideología I, 147-152.

BEARD, M.: Introducción a los clásicos. Madrid, Acento, 1998.

Beltrán Almería, L.: «El debate sobre el género en la novela antigua», $\triangle \iota \delta \alpha \sigma \kappa \alpha \lambda \sigma \varsigma 259-278$.

BERNABÉ, A.: «La épica griega», Géneros literarios poéticos 9-38.

BRIOSO SÁNCHEZ, M.: «Aspectos formales del relato en la novela griega antigua», Actitudes literarias 123-207.

Brioso SÁNCHEZ, M.: «De nuevo sobre los orígenes de la poesía bucólica: iTe-

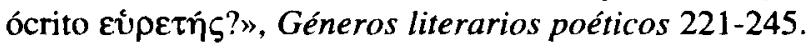

BRIOSo SÁnChEZ, M.: «Observaciones sobre los proemios "programáticos" y las tesis de Conte», Habis 29, 1998, 87-100.

BRIoso SÁnchez, M.: «La novela griega antigua y la unidad libro», SPhV 3, 1998, 5-18. 
Cabrillana, C.: «Funcionalidad de la ruptura de la ilusión escénica: de Aristófanes a Terencio», Corolla Complutensis 263-272.

CANDAU, J.M.: «La irrupción de los dioses. Lo sobrenatural como elemento de fractura en la historiografía helenística», Religión, magia y mitología 61-79.

Cavallo, G.; Chartier, R.; Bonfil, R.: Historia de la lectura en el mundo occidental. Trad. de M. Barberán, M.P. Palomero, F. Borrajo y C. García Ohlrich. Madrid, Taurus, 1998.

Conde Calvo, J.L.: «Tiempo y género en la narrativa grecolatina», $C F C L 15$, 1998, 97-105.

CONTI Bizarro, F.: «Sull'impiego di forme inniche nella commedia greca», Dramaturgia y puesta en escena 251-266.

CORTÉs GABAUdÁN, F.: «Narrar argumentando en oratoria e historiografía griegas», Actas del IX Congreso IV, 117-122.

CRISCUOLO, U.: «Il secondo prologo nella tragedia greca», Dramaturgia $y$

puesta en escena 67-83.

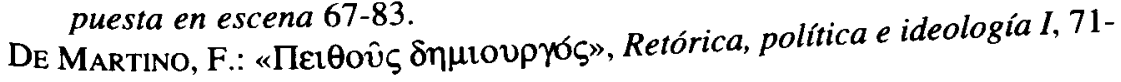
77.

DEGANI, E.: «L'elemento gastronomico nella commedia greca postaristofanea", La comedia griega y su influencia 215-225.

DESIDERI, P.: «Passato e presente nella storiografia greca alto-imperiale», X $\alpha \hat{\imath} \rho \varepsilon$ 365-371.

Díaz Rolando, E.: «De la historia al encomio histórico en Grecia», Actas del IX Congreso IV, 129-132.

FIALHO, M.C.: «A retórica na tragédia greca: horizonte político da sua utilização dramática», Retórica, política e ideología I, 185-190.

GALAZ, M.T.: «Valores morales y represión en Atenas: la etopeya en la oratoria forense», Actas del IX Congreso VI, 87-93.

García Castillo, P.: «Retórica y cinismo», Retórica, política e ideología I, 235-239.

García Novo, E.: «Simetría y variación en el teatro y en el arte griegos: el problema de las libertades de responsión (Responsionsfreiheiten)», Dramaturgia y puesta en escena 121-150.

GARCía SOLER, M.J.: «La comida y la bebida en la lírica arcaica griega», Actas del IX Congreso VI, 99-103.

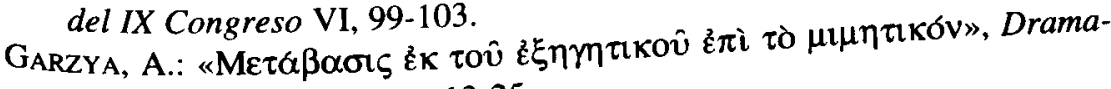
turgia y puesta en escena 13-25.

Giangrande, G.: «The Carmina asisinatia in the Light of Hellenistic Poetry", Myrtia 12, 1997, 9-24.

GIL Fernández, L.: «La risa y lo cómico en el pensamiento antiguo», La comedia griega y su influencia 307-343. 
Gómez Espelosín, F.J.: «Paradoxografía e historiografía helenística», X $\alpha \hat{\imath} \rho \varepsilon$ 275-283.

GonZÁleZ Iglesias, J.A.: «Hacia la definición de un género literario: el diálo-

go. La mujer como interlocutora», Actas del IX Congreso IV, 179-183.

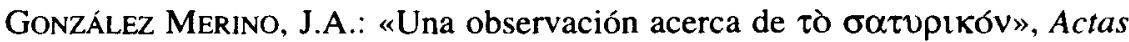
del IX Congreso IV, 185-190.

GonZÁleZ PONCE, F.J.: «El Corpus periplográfico griego y sus integrantes más antiguos: épocas arcaica y clásica», Los límites de la tierra 41-75.

GONZÁLEZ PONCE, F.J.: «Utilidad práctica, ciencia y literatura en la periplografía griega de época helenística», Los límites de la tierra 147-175.

GonzÁlez Terriza, A.A.: «La destrucción o el amor: cuentos de Lamia en el mundo antiguo", Actas del IX Congreso IV, 191-196.

KAKRIDIS, PH.J.: «A survey of the Greek epic from its beginnings to the epic of Digenis Akritas», Actas del IX Congreso IV, 203-206.

La Península lbérica en los autores griegos: de Homero a Platón. Edición, traducción y comentario de E. Gangutia Elícegui. INSCRIPTIONES GRAECAE ANTIQUISSIMAE IBERIAE (IGAI). Edición, traducción y comentario de H. Rodríguez Somolinos. Testimonia Hispaniae Antiqua II A. Madrid, Universidad Complutense - Fundación de Estudios Romanos, 1998.

LAGUNA MARISCAL, G.: «La poesía epigramática griega en su relación con la literatura romana: el tema amoroso», Actitudes literarias 93-121.

Lillo REDONET, F.: «La mujer en la consolación filosófica antigua», Actas del IX Congreso VI, 159-164.

LÓPEZ EIRE, A.: «Helenismo, antigüedad tardía, retórica y epistolografía», Actitudes literarias 319-347.

LÓPEZ EiRE, A.: «La etimología de óvi $\tau \omega \rho$ y los orígenes de la retórica», $\mathrm{Fa}$ ventia 20/2, 1998, 61-69.

LÓPEZ FÉREZ, J.A.: «La tragedia griega», Géneros literarios poéticos 129-166.

LOPEZ SALVÁ, M.: "La retórica del mito en la fundación de ciudades», Retórica, política e ideología I, 45-50.

Martín Velasco, M.J.: «El talante del orador en la persuasión», Corolla Complutensis 323-328.

MARTíneZ, M.: «Apuntes para una historia de la literatura erótica griega», $A C$ tas del IX Congreso IV, 225-228.

MARTínez, M.: «Los himnos a Eros en la literatura griega», Corolla Complutensis 187-198.

Massullo, R.: «Contributo allo studio dell'Anrede nella tragedia greca», Dramaturgia y puesta en escena 27-37.

MASTROMARCO, G.: «La commedia antica fra tradizione e innovazione», La comedia griega y su influencia 23-42. 
MAtino, G.: «Terminologia della scena nella tragedia attica», Dramaturgia y puesta en escena 151-166.

Mauron, C.: Psicocrítica del género cómico. Aristófanes, Plauto, Terencio, Molière. Madrid, Arco Libros, 1998.

Melero, A.: «La comedia prearistofánica», Actas del IX Congreso IV, 3-26.

MELERO, A.: «La formación de la poética cómica», Géneros literarios poéticos 183-207.

MELERo, A.: «La dramaturgia del drama satírico», Dramaturgia y puesta en escena 205-217.

Miguel Jover, J.L. DE: «La tragedia del s. IV a.C.: revisión de una vieja polémica», Actas del IX Congreso IV, 251-258.

MELERO, A.: «Los predecesores de Aristófanes», La comedia griega y su influencia 63-80.

Molina Moreno, F.: «Somnium pythagoreum. En torno a la armonía de las esferas», Actas del IX Congreso VI, 187-192.

Morales, G.: Antología de la literatura erótica. Madrid, Espasa, 1998.

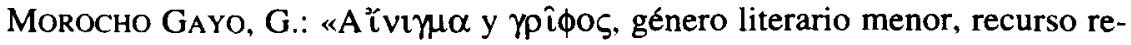
tórico y método de interpretación», Corolla Complutensis 335-344.

Navarro, J.L.: «La figura de Ulises en la tragedia griega», Actas del IX Congreso IV, 265-269.

Perusino, F.: «Tra commedia antica e commedia nuova: considerazione sul ruolo della commedia di mezzo nella cultura greca del IV secolo», La comedia griega y su influencia 203-214.

PiCklesimer, M.L.: «El Ciclo Épico troyano a la luz del Mahabharata», Religión, magia y religión 167-200.

Rispol, G.M.: «La voce dell'attore: teorie e tecniche (Parte I)», Dramaturgia y puesta en escena 53-65.

RODRÍGUEz ADRADOS, F.: «Tragedia y comedia», La comedia griega y su influencia 1-22.

Ruiz Montero, C.: «El concepto de $\lambda \xi \xi$ is en la teoría estilística griega», $R e$ tórica, política e ideología l, 91-99.

SÁnChez PALlín, F.J.: «La retórica: ¿una lucha deportiva?», Retórica, política e ideología I, 11-122.

SANCHIS, J.: «La evolución de un motivo simposial en la comedia griega», Corolla Complutensis $227-232$.

SANCHO RoYo, A.: «Retórica e historiografía en la época helenístico-imperial», Actitudes literarias 295-317.

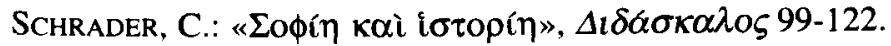

SILva SÁNCHEZ, T.: «Aproximación al contenido y estructura de las obras griegas sobre caza», Actas del IX Congreso IV, 323-327. 
SOMmERSTEIN, A.H.: «The theatre audience and the Demos», La comedia griega y su influencia 43-62.

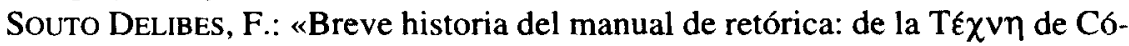
rax a la Retórica de Aristóteles», Retórica, política e ideología I, 79-84.

SOUTO Delibes, F.: «Relaciones personales entre comediógrafos de la comedia griega antigua», Corolla Complutensis 233-238.

SuÁREZ DE LA TORRE, E.: «La lírica griega», Géneros literarios poéticos 105.

SUÁREZ DE LA TORRE, E.: «Observaciones sobre la presencia de la mántica en la Comedia griega», La comedia griega y su influencia 177-201.

TORRE, E.: La poesía de Grecia y Roma: ejemplos y modelos de la cultura literaria moderna. Huelva, Universidad - Consejo Superior de Investigaciones Científicas, 1998.

TORRES GUERRA, J.B.: «El héroe como orador», Retórica, política e ideología I, 39-43.

UREÑA BraCero, J.: «Caracterización de campesino en las cartas miméticas», Actas del IX Congreso IV, 34 1-350.

URÍAS MARTíneZ, R.: «La retórica como instrumento de promoción en la parte oriental del imperio», X $\alpha \hat{\imath} \rho \varepsilon$ 391-403.

VAN Duj, G.-J.: «Suplemento al inventario de la fábula greco-latina. Épocas arcaica, clásica y helenística», Emerita 66, 1998, 15-22.

VillarRubia MEdina, A.: «La himnografía griega de época imperial», Actitudes literarias 9-76.

\section{Lingǘística GRIEgA. Métrica}

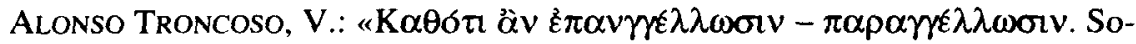

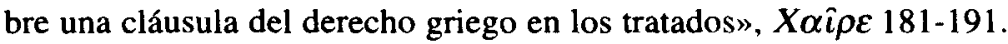

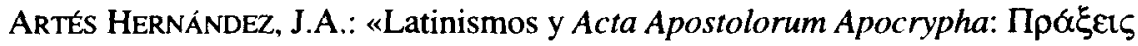

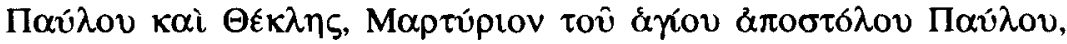

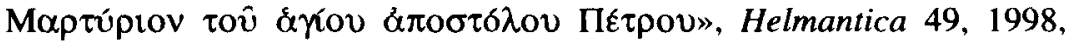
285-307.

ARTÉs HERnÁNDEZ, J.A.: “ ¿Griego neotestamentario y traducciones interesadas?», Myrtia 12, 1997, 89-100.

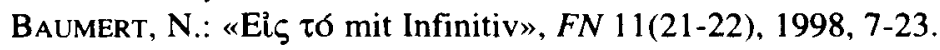

BERNABE, A.: «Linguística antes de la lingüística. La génesis de la indagación sobre el lenguaje en la Grecia antigua», R.S.E.L. 28, 1998, 307-331.

Bernabé, A.: «Hom. \& $\alpha \phi i ́ \beta p o \tau o \zeta$ y mic. a-pi-qo-to, ¿un caso de etimología popular?», Corolla Complutensis 39-48.

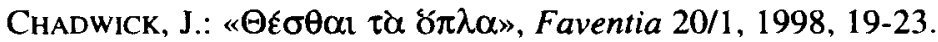


DÍAZ DE CERIO, M.: «La codificación de la asociación-compañía como segundo término argumental de la predicación en griego antiguo», R.S.E.L. 28, 1998, 421-451.

CRESPO, E.: «Niveles sintácticos de la estructura de la oración principal simple en griego clásico», Nombres y funciones 43-63.

CRESPO, E.: «Los sintagmas nominales en aposición oracional y la descripción semántica de la oración», Corolla Complutensis 63-66.

DE WaAl Dryden, J.: «The Sense of $\sigma \pi \varepsilon \rho \mu \alpha$ in 1 John 3:9. In Light of Lexical Evidence», FN 11(21-22), 1998, 85-99.

DÍAZ DE CERIO, M.: «Predicaciones bivalentes de semejanza en griego antiguo», Corolla Complutensis 67-76.

Durán, A.: «El concepto de Kóojos en el Encomio de Helena», Corolla Complutensis 179-186.

GarCía de LA Fuente, O.: «Abyssos y abyssus en la Biblia griega y latina», ACtas del IX Congreso V, 87-91.

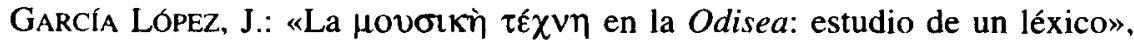
Corolla Complutensis 363-368.

GARCía Romero, F.: «Esquilo, Suplicantes 524-536: análisis métrico», Corolla Complutensis 377-282.

García TEIJEIRo, M.: «Consideraciones sobre el vocabulario griego de la magia», Corolla Complutensis 99-104.

Gastaldi, V.; Gambon, L.: «Algunas consideraciones en torno a ßoú $\lambda \varepsilon v \sigma l \zeta$

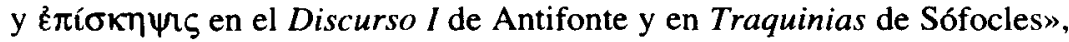
Retórica, política e ideología I 179-184.

Hoz GaRCía-Bellido, M.P.: «El verbo $\kappa \alpha \theta t \varepsilon \rho o ́ \omega$ y la consagración de un difunto a la divinidad", Actas del IX Congreso VI, 141-145.

IRIARTE, A.: «El nombre de Efialtes», X $\alpha \hat{\imath} \rho \varepsilon$ 175-179.

LABIANO ILUNDAIN, J.M.: «Griego elév. Sobre un uso concreto y su distribución», Retórica, política e ideología I, 15-24.

LILlo, A.: «Los genitivos en - $\alpha$ Fo de Corcira y Gela», Corolla Complutensis 49-54.

LÓPEZ EIRE, A.: «Sóbre el ático coloquial de la Comedia aristofánica», La comedia griega y su influencia 137-175.

LÓPEZ EIRE, A.: «La etimología de $\rho$ ń $\tau \omega \rho$ y los orígenes de la retórica», Faventia 20/2, 1998, 61-69.

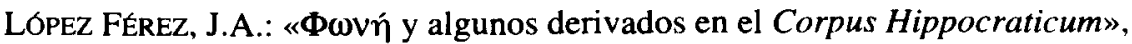
Corolla Complutensis 423-432.

MaKuJINA, J.: «Verbs meaning "command" in the New Testament: determining the factors involved in the choice of command-verbs", $E B 56$, 1998, 357-369. 


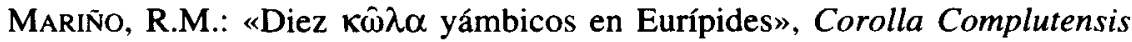
383-388.

Martín García, F.: «Las cesuras en los hexámetros de los Cinegética de Opiano», Corolla Complutensis 389-396.

MARTín VELASCO, M.J.: «Función de las interrogativas retóricas planteadas como hipótesis», Retórica, política e ideología 1, 31-37.

MARTíneZ FERnÁndEZ, Á.: «Estudio sobre el vocabulario jurídico en el dialecto cretense", Fortunatae 9, 1997, 103-123.

MARTORELl, E.: El griego del Nuevo Testamento. Terrasa, Clíe, 1998.

MÉndez DosunA, J.: «Frecuencia textual y complejidad morfológica: los adverbios de lugar en griego clásico», Corolla Complutensis 91-98.

JIMÉNEZ, M.D.: «La expresión de relaciones temporales en ático clásico», Nombres y funciones 65-110.

ORTEGa Villaro, B.: «La distribución de imperativo, futuro e infinitivo-imperativo en las inscripciones dialectales cretenses», $C F C G$ 8, 1998, 185-208. Pabón de ACuÑa, C.T.: «E’́k $\omega$ en Sófocles: la intransigencia del héroe», Corolla Complutensis 173-178.

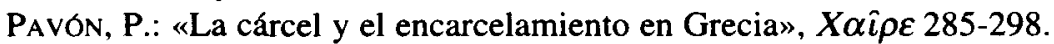

Pertini, M.A.: «La genialidad gramatical de Jn 8,25», EB 56, 1998, 371-404.

RAMÓN PALERM, V.: «La lengua literaria de Aristófanes: aspectos didácticos», $\triangle \imath \delta \alpha ́ \sigma \kappa \alpha \lambda o \zeta$ 63-98.

REPERTORIO BIBLIOGRÁFICO DE LA LEXICOGRAFIA GRIEGA (RBLG). Redactado por P. Boned Colera. Revisado, corregido y aumentado por J. Rodríguez Somolinos con la colaboración de E. Vallines Menéndez, J. Martínez de Tejada Garaizábal y E. Luján Martínez. Diccionario Griego-Español, Anejo III. Madrid, Consejo Superior de Investigaciones Científicas, 1998.

Rodríguez AdRAdos, F.: La dialectología griega, hoy (1952-1995). Madrid, Ediciones Clásicas, 1998.

Rodríguez Somolinos, H.: El léxico de los poetas lesbios. Diccionario Griego Español, Anejo IV. Madrid, Consejo Superior de Investigaciones Científicas, 1998.

Ruiz MonTERo, C.: «El concepto de $\lambda \varepsilon \xi \xi ı$ en la teoría estilística griega», $R e-$ tórica, política e ideología I, 91-99.

Ruiz YamuZA, E.: «Sintaxis, semántica y pragmática de la asignación de sujeto en pasiva en griego clásico», R.S.E.L. 28, 1998, 333-358.

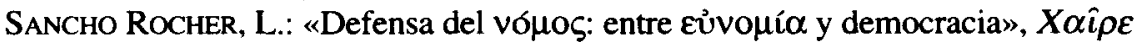
139-153.

SERRANO, R.: «Análisis gráfico, capacidad articulatoria y estructura del sistema: consideraciones en torno al desplazamiento $/ \delta />/ \tilde{u} /$ en el dialecto de Argos», Corolla Complutensis 55-62. 
VAlverde, M.: «El léxico musical en Calímaco», Corolla Complutensis 369. 376.

Vela Tejada, J.: «Dativo de plural en griego antiguo: problemas y métodos de análisis lingüístico», $\Delta t \delta \alpha ́ \sigma \kappa \alpha \lambda \circ \varsigma$ 123-155.

VílCHEZ, M.: «Algunas reflexiones sobre la categoría del número», R.S.E.L. 28, 1998, 115-130.

VILLA POLO, J. DE LA: «La agentividad en la lengua homérica», Nombres y funciones $147-180$.

\section{Micenología}

Bennet, E.L.: «Junctions, Restorations, and Reconstructions in Pylian and Related Texts», Minos 31/32, 1996/97, 135-143.

Chadwick, J.: «Three Temporal Clauses», Minos 31/32, 1996/97, 293-301.

Del Freo, M.: «Osservazioni su miceneo ko-ma-we-te-ja», Minos 31/32, 1996/97, 145-158.

Demakopoulo, K.: «An Early Mycenaean Inscribed Sherd from pylos», Minos 31/32, 1996/97, 447-448.

FIRTH, R.J.: «The Find-Places of tha Tablets from the Palace of Knossos», Minos 31/32, 1996/97, 7-122.

GaRCía RAMón, J.L.: «Eine wichtige Studie über die Nomina auf -tãs und -ãs im Mykenischen», Minos 31/32, 1996/97, 423-432.

Halstead, P.: «Linear B Evidence for the Management of Sheep Breeding at Knossos: Production Targets and Deficits in the KN DI(1) and Do Sets", Minos 31/32, 1996/97, 187-199.

KILLEN, J.T:: «The Find-Places of the Tablets from the Western Magazines at Knossos. Some Matters Arising», Minos 31/32, 1996/97, 123-132.

KILLEN, J.T.: «Mycenaean te-ko-to-(n)a-pe», 179-185.

KYRIAKIDIS, E.: «Some Aspects of the Rôle of Scribes in Pylian Palace Administration», Minos 31/32, 1996/97, 201-229.

LEJDEGERD, H.: «Some Observations on qa-si-re-u», Minos 31/32, 1996/97, 371-378.

LuJÁN, E.R.: «El léxico micénico de las telas», Minos 31/32, 1996/97, 335-369.

MelENA, J.L.: «40 Joins and Quasi-joins of Fragments in the Linear B Tablets from Pylos", Minos 31/32, 1996/97, 159-170.

MelenA, J.L.: «13 Joins and Quasi-joins of Fragments in the Linear B Tablets from Pylos», Minos 31/32, 1996/97, 171-178.

MelenA, J.L.: «20 raccords et quasi-raccords de fragments dans les tablettes de Cnossos», Minos 31/32, 1996/97, 417-422. 
OLIVIER, J.P.: «El comercio micénico desde la documentación epigráfica», $M i$ nos 31/32, 1996/97, 275-292.

PAlaimA, T.G.: «po-re-na: A Mycenaean Reflex in Homer? An I-E Figure in Mycenaean?», Minos 31/32, 1996/97, 303-312.

Pluta, K.: "A Reconstruction of the Archives Complex at Pylos: Preliminary Progress Report», Minos 31/32, 1996/97, 231-250.

SCHOEP, I.: «Sealed documents and data processing in Minoan Administration:

A Review Article», Minos 31/32, 1996/97, 401-415.

ThOMPSON, R.: «Dialects in Mycenaean and Mycenaean among the Dialects», Minos 31/32, 1996/97, 313-33.

Van Alfen, P.: «The LM IIIB Inscribed Stirrup-Jars as Links in an Administrative Chain», Minos 31/32, 1996/97, 251-274.

WalberG, G.: «Two New Nodules from the Lower Terraces at Midea», Minos 31/32, 1996/97, 133-134.

YOUNGER, J.G.: «The Cretan Hieroglyphic Script: A Review Article», Minos $31 / 32,1996 / 97,379-400$.

6. Epigrafía. Papirología

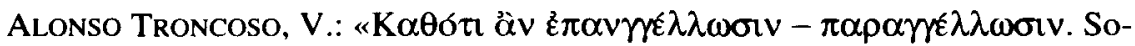

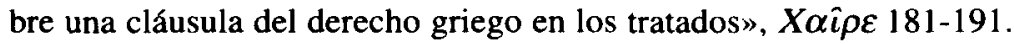

ÁlvareZ Baños, M.I.: «Una aproximación a la magia de los papiros griegos», Actas del IX Congreso VI, 37-40.

BAÑuls Oller, J.V.: «De la pétrea memoria y el áureo olvido: los epitafios y las lamellae aureae», SPhV 2, 1997, 5-22.

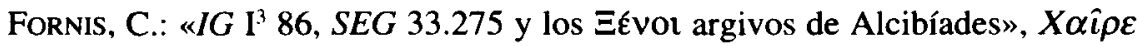
193-201.

Garcia SOLER, M.J.: «La alimentación en la antigua Cirene y las cuentas de los demiurgos", $C F C G$ 8, 1998, 209-221.

Guinea Diaz, P.: «Las Demostenias de Enoanda y los bueyes aldeanos», Xoî $\rho \varepsilon$ 463-471.

la Peninsula lbérica en los autores griegos: de Homero a Platón. Edición, traducción y comentario de E. Gangutia Elícegui. INSCRIPTIONES GRAECAE ANTIQUISSIMAE IBERIAE (IGAI). Edición, traducción y comentario de H. Rodríguez Somolinos. Testimonia Hispaniae Antiqua II A. Madrid, Universidad Complutense - Fundación de Estudios Romanos, 1998.

Macía Aparicio, L.M.: «Lista de papiros para una edición de la Ilíada», Tempus 20, 1998, 5-57. 
MARTínez Fernández, Á.: «La mujer en los epigramas cretenses de época imperial», Actas del IX Congreso VI, 171-175.

MARTínez FernándeZ, Á.: «Un epigrama funerario de Creta», Corolla Complutensis 243-248.

ORTEGa VILlaRo, B.: «Las Tablas de Heraclea: traducción y notas», Habis 29, 1998, 51-67.

OVADIAH, A.: «Allegorical Images in Greek Laudatory Inscriptions in Eretz-Israel», Gerión 16, 1998, 383-394.

\section{HistoRIA DE LOS TEXTOS}

Barcenilla, A.: «Bibliotecas de la Edad Media: Las Bibliotecas Catedralicias», Perficit 22, 1998, 99-178.

BÉCAREs, V.: «Notas filológicas a la noción de canon», Corolla Complutensis 563-568.

BERSCHIN, W.: «Elementos griegos en códices manuscritos latinos de la Edad Media», Actas del IX Congreso VII, 65-73.

Bravo Garcia, A.: «El Aristófanes de las bibliotecas de la Comunidad de Madrid: una ojeada a los fondos de El Escorial», La comedia griega y su influencia 369-386.

FLORISTÁN, J.M.: «El fondo Giustiniani de códices griegos en El Escorial», Corolla Complutensis 569-578.

Martínez Manzano, T.: «Los escolios aristofánicos del Matr.4629 y el humanismo griego del Quattrocento», Corolla Complutensis 579-582.

Martínez Manzano, T.: «El Salm.2659 de Dioscórides y la historia del fondo griego de la Biblioteca Universitaria de Salamanca procedente del Colegio de San Bartolomé», Helmantica 49, 1998, 309-328.

PÀmias I Massana, J.: «Sobre el fragment dels Catasterisms d'Eratòstenes del manuscrit Parisinus Graecus 1310: el nom dels planetes Saturn i Júpiter", Faventia 20/2, 1998, 71-77.

Romero TAllafigo, M.; Rodríguez liáñez, L.; SÁNChEZ GonZÁlez, A.: $E l$ arte de leer escrituras antiguas. Paleografía de lectura. 2.a ed. revisada y ampliada. Huelva, Universidad, 1998.

SATUE, E.: El diseño de libros del pasado, del presente, y tal vez del futuro: la huella de Aldo Manuzio. Madrid, Fundación Germán Sánchez Ruipérez, 1998.

WeInSTEIN, K.: El arte de los manuscritos medievales. Traducción de O. Miró. Barcelona, Edunsa, 1998. 


\section{Historia. Cultura. Sociedad}

Alfaro Giner, C.; Noguera Borel, A.: La mujer en la Antigüedad. Actas del primer seminario de estudios sobre la mujer en la Antigüedad (Valencia, 24-25 de Abril de 1997). Valencia, Universidad, 1998.

Barceló, C.: La Atlántida. Madrid, Edimat, 1998.

BERMEJO BARRERA, J.C.: «Sobre las dimensiones significativas del espacio», Los límites de la tierra 1-22.

Bermejo Barrera, J.C.: «Narrar, explicar, pensar», Polis 9, 1997, 5-24.

Bianchi Bandinelli, R.; PARIBENI, E.: El arte de la antigüedad clásica. Madrid, Akal, 1998.

BlázQuez, J.M.: Intelectuales, ascetas y demonios al final de la antigüedad. Madrid, Cátedra, 1998.

Braudel, F.: Memorias del Mediterráneo. Prehistoria y antigüedad. Edición de R. Ayala y P. Braudel. Prefacio y notas de J. Guilaine y P. Rouillard. Traducción de A. Martorell. Madrid, Cátedra, 1998.

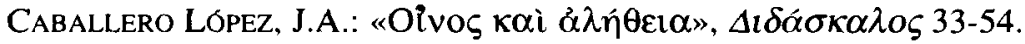

Cabrera Bonet, P.; Sánchez Fernández, C. (eds.): Los griegos en España: tras las huellas de Heracles (Exposición). Madrid, Ministerio de Educación y Cultura, 1998.

CAMERon, A.: El mundo mediterráneo en la antigüedad tardia 395-600. Traucción de T. de Lozoya. Barcelona, Crítica, 1998.

CANFORA, L.: La biblioteca desaparecida. Gijón, Trea, 1998.

Ciprés Torres, P.; Cruz AndreotTi, G.: «El diseño de un espacio político: el ejemplo de la Península Ibérica», Los límites de la tierra 107-145.

ClogG, R.: Historia de Grecia. Traducción de H. Aixendri Boneu. Madrid, Cambridge University Press, 1998.

Connolly, P.; Dodge, H.: La ciudad antigua. La vida en la Atenas y Roma clásicas. Traducción de P. Ripollés y R. Cifuentes. Madrid, Acento, 1998.

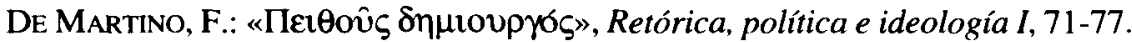

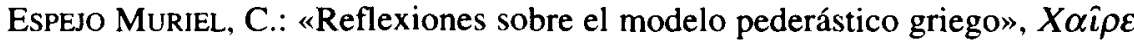
379-390.

ESTEBAN LORENTE, J.F.: Tratado de iconografia. Madrid, Istmo, 1998.

ÉTIENNE, R.: La antigua Grecia. Historia de la arqueología helenística. Madrid, Biblioteca de Bolsillo Claves, 1998.

FAU, M.T.: «La moneda griega a través de los textos», Actas del IX Congreso VI, 83-86.

Ferrer Albelda, E.; Bandera Romero, M.L. DE la: «La localización de Mastia: un aspecto problemático de los conocimientos griegos sobre Ibe-

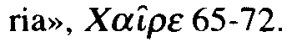


Fraga Iribarne, A.: De Criseida a Penélope : un largo camino hacia el patriarcado clásico. Madrid, Horas y Horas, 1998.

Gómez Espelosín, F.J.: Introducción a la Grecia antigua. Madrid, Alianza, 1998.

GonZÁlez, J. (ed.): El mundo mediterráneo (siglos III-VII). Madrid, Ediciones Clásicas, 1998.

Grimal, P.: Los extraños de la libertad. Madrid, Gedisa, 1998.

Hidalgo de la Vega, M.J.; Sayas Bengoechea, J.J.; Roldán Hervás, J.M.: Historia de la Grecia Antigua. Salamanca, Universidad, 1998.

Hubeñak, F.: «Pericles y la sociedad de su época», MHA 17, 1996, 9-53.

JANNI, P.: «Los límites del mundo entre el mito y la realidad. Evolución de una imagen», Los límites de la tierra 23-40.

JENKINS, I.: La vida cotidiana en Grecia y Roma. Madrid, Akal, 1998.

la Península lbérica en los autores griegos: de Homero a Platón. Edición, traducción y comentario de E. Gangutia Elícegui. INSCRIPTIONES GRAECAE ANTIQUISSIMAE IBERIAE (IGAI). Edición, traducción y comentario de $\mathrm{H}$. Rodríguez Somolinos, en J. Mangas y D. Plácido (eds.), Testimonia Hispaniae Antiqua II A. Madrid, Universidad Complutense - Fundación de Estudios Romanos, 1998.

LóPEZ DE JuAN, C.; Plácido, D. (eds.): Momentos estelares del mundo antiguo. Madrid, Ediciones Clásicas, 1998.

LuQue TERUEL, A.: Sobre el urbanismo en la Hélade (de la fortaleza aquea a la polis arcaica). Sevilla, s.n., 1998.

MARÍN SÁNCHEZ, R.: La construcción en la época griega. Valencia, Universidad Politécnica, 1998.

MAYER, M.; RODA, I. (coord.): Ciudades antiguas del Mediterráneo. Barcelona, Lunwerg, 1998.

MigeotTe, L.: «Finances sacrées et finances publiques dans les cités grecques», Actas del IX Congreso VI, 181-185.

Montanelli, I.: Historia de los griegos. Barcelona, Plaza \& Janés, 1998.

ORLANDIS, J.: Historia de la Iglesia I. La Iglesia antigua y medieval. Madrid, Palabra, 1998.

OsboRne, R.: La formación de Grecia, 1200-479 A.C. Barcelona, Crítica - Grijalbo-Mondadori, 1998.

PÉrez JimÉnez, A.: «La imagen celeste de la Ecumene. Geografía zodiacal y planetaria», Los límites de la tierra 177-219.

PÉrez JiMÉNeZ, A.: «Mito y astrología en Grecia: un viaje con retorno», Religión, magia y mitología 137-165.

Pérez Jiménez, A.; Cruz Andreotti, G.: «Quid plus ultra? Conciencia geográfica de los antiguos», Los límites de la tierra VII-X. 
Pérez largacha, A.: «Egipto y el Egeo en la segunda mitad del II milenio», Actas del IX Congreso VI, 201-205.

Plácido, D.; Fornis, C.; Casillas, J.M.: La Guerra del Peloponeso. Madrid, Ediciones Clásicas, 1998.

PRONTERA, F.: «Sobre la delineación de Asia en la geografía helenística», Los límites de la tierra 77-105.

Real Torres, C.: «¿Brujas o ángeles? Algunos ejemplos de misoginia en el mundo clásico», Fortunatae 9, 1997, 223-235.

Ruiz LÓPEZ, D.: «Mujeres licias (Plut.Mul.Virt.9.248D)», Actas del IX Congreso VI, 219-224.

SANTIAGO, R.A.: «Griegos y bárbaros: arqueología de una alteridad», Faventia 20/2, 1998, 33-44.

SID AHMED, A.: El Mediterráneo de la integración a la fragmentación: los intercambios de la Antigüedad a nuestros días. Datos, fundamentos históricos y perspectivas. Barcelona, Centre d'Informació i Documentació Internacionals de Barcelona, 1998.

TEJA, R. (ed.): Cristianismo marginado: rebeldes, excluidos, perseguidos I. De los orígenes al año 1000. Actas del XI Seminario sobre Historia del Monacato (Aguilar de Campoo, 4-7 de Agosto de 1997. Aguilar de Campoo - Madrid, Fundación Santa María la Real - Polifemo, 1998.

WiLl, E.; Mossé, C.; Goukowsky, P.: El mundo griego y el Oriente II: el siglo IV y la época helenística. Madrid, Akal, 1998.

9. Religión. Mitología

AgUiRRE, M.: «Fórmulas y expresiones genealógicas en la Teogonía: las descendencias de Noche y Gea», Corolla Complutensis 461-468.

Álvarez Baños, M.I.: «Una aproximación a la magia de los papiros griegos», Actas del IX Congreso VI, 37-40.

Álvarez de MiRanda, A.: Ritos y juegos del toro. Madrid, Biblioteca Nueva, 1998.

Argárate, P.: Portadores del fuego: la divinización en los padres griegos. Bilbao, Desclée de Bouwer, 1998.

Ballesteros Pastor, L.: «La leyenda de las Amazonas en la historia de Mi-

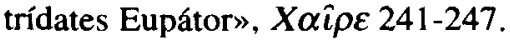

Beltrán Noguer, M.T.: "Mitología y música», Actas del IX Congreso VII, 61-64.

Bermejo Barrera, J.C.: «Mitología clásica y antropología», Habis 29, 1998, 335-347. 
Bermejo Barrera, J.C.; Fernández Canosa, X.A.: «Mito y método histórico: el ejemplo de Ártemis", $X \alpha \hat{\imath} \rho \varepsilon$ 37-56.

BonNefoy, I. (dir.): Diccionario de las mitologías, Vol. IV. Las mitologías de Europa: los indoeuropeos y los «otros». El chamanismo asiático. Edición a cargo de J. Pòrtulas y M. Solana. Traducción de M. Solana. Barcelona, Destino, 1998.

Buenacasa PÉrez, C.: «La decadencia y cristianización de los templos paganos a lo largo de la Antigüedad Tardía (313-423)", Polis 9, 1997, 25-50.

Calvo MARTínez, J.L.: «Magia literaria y magia real», Religión, magia y mitología 39-59.

CAmpbell, J.: El vuelo del ganso salvaje : exploraciones en la dimensión mitológica. Traducción de D. González Raga y F. Mora. Barcelona, Kairós, 1998.

Caudet Yarza, F.: Diccionario de mitología. Madrid, Edimat, 1998.

Cencillo, L.: Historia sistémica de los dioses. Madrid, Fundación Cencillo de Pineda, 1998.

CIRLOT, J.E.: El ojo en la mitología: su simbolismo. Madrid, Huerga y Fierro, 1998.

CORDIANO, G.: «Lo "Zeus dell' Alece”: una proposta di localizzazione», Gerión $16,1998,161-175$.

CORNelius, G.: Manual de los cielos y sus mitos. Guia práctica para observar el cielo nocturno, sus mitos y símbolos. Barcelona, Naturart, 1998.

CRistóbal LóPez, V.: «Hero y Leandro», Amores míticos 195-221.

CUARTERo IBORRA, F:J.: «Heràcles, fundador de sacrificis: l'heroi i les tres funcions», Faventia 20/2, 1998, 15-25.

Diccionario de la mitología mundial. Prólogo de R. Fontán Barreiro. Madrid, Edaf, 1998.

DiEL, P.: El simbolismo en la mitología griega. Barcelona, Idea Books, 1998.

DíEz DE VELASCO, F.: Lenguajes de la religión, Mitos, símbolos e imágenes de la Grecia antigua. Madrid, Trotta, 1998.

DuCH, LL.: Mito, interpretación y cultura. Aproximación a la logomítica. Barcelona, Herder, 1998.

Esteban, A.; Aguirre, M.: Cuentos de la mitología griega III. En el mar. Ilustraciones de S. López. Madrid, Ediciones de La Torre, 1998.

Flores Santamaría, P.: «Polifemo y Galatea», Amores míticos 55-79.

Frazer, J.G.: Objetos y palabras tabú. Madrid, Fondo de Cultura Económica de España, 1998.

Galé CASAJús, E.: Los héroes de la antigua Grecia. Zaragoza, Alcaraván, 1998. Gangutia Elícegui, E.: «Gerioneidas. Desarrollo literario griego en contacto con el Próximo Oriente», Emerita 66, 1998, 231-256. 
García Gual, C.: "Tetis y Peleo», Amores míticos 247-260.

GARCÍA LÓPEZ, J.: «Música y religión en Grecia», Religión, magia y mitología 83-100.

García Masegosa, A.: Los amores humanos de Zeus. Vigo, Universidad, 1998.

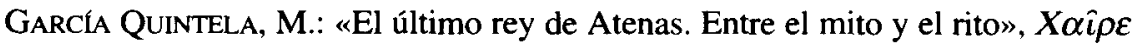
21-35.

GARCÍA SANZ, Ó.: «Amazonas: una realidad histórica para la tradición occidental y la del nuevo mundo», $A M 21,1998,609-622$.

García TeljEIRo, M.: "Consideraciones sobre el vocabulario griego de la magia», Corolla Complutensis 99-104.

GASPERINI, L.: «Cultos de héroes fundadores: Batos en Oriente, Taras en Occidente», Gerión 16, 1998, 143-159.

GonzÁlez MARrero, J.A.; LeÓN Rolo, B.: «El universo en los mitos clásicos», Fortunatae 9, 1997, 193-202.

Grant, M.; HAZEL, J.: Diccionari de mitologia clássica. Barcelona, Enciclopédia Catalana, 1997.

Graves, R.: Los mitos griegos. Madrid, Alianza, 1998.

GrigoriefF, V.: Mitologías occidentales. Traducción de D. Chiner. Barcelona, Robinbook, 1998.

Grupo TemPe: Los dioses del Olimpo. Madrid, Alianza, 1998.

GUERBER, H.A.: Grecia y Roma. Barcelona, Edimat, 1998.

Guerra GOMEz, M.: «El sacerdocio femenino y su castidad en la antigüedad greco-romana», Actas del IX Congreso VI, 113-119.

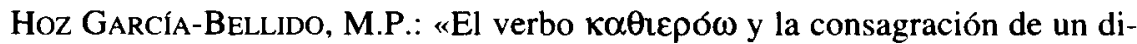
funto a la divinidad», Actas del IX Congreso VI, 141-145.

KERÉNYI, K.: Dionisos. Raiz de la vida indestructible. Barcelona, Herder, 1998. LENS TUERo, J.: “Gimnasios en el paraíso», Actas del IX Congreso VI, 153157.

LÓPEZ SACO, J.: «Los orígenes de Heracles y su desarrollo cultual», Fortunatae 9, 1997, 59-79.

LÓPEZ SALVÁ, M.: «La retórica del mito en la fundación de ciudades», Retórica, política e ideología I, 45-50.

LÓPEZ SALVÁ, M.: «Del concepto triádico al trinitario en la religión antigua», Corolla Complutensis 497-504.

Macia APARICio, L.: «Fedra e Hipólito», Amores míticos 261-280.

MARTIN, R. (dir.): Diccionario de la mitología clásica. Madrid, Espasa-Calpe, 1998.

MARTín García, J.A.: «Los mitos griegos de la creación. La Cosmogonía», CFCG 8, 1998, 109-131. 
MARTín SÁnChEZ, M.A.: «Venus y Marte», Amores míticos 166-194.

MARTínez Nieto, R.B.: «Пópo̧: una divinidad cosmogónica olvidada», Actas del IX Congreso IV, 229-233.

MAyor FerRÁndiz, T.M.: «Cleonice, la mensajera de Némesis», Actas del IX Congreso IV, 239-244.

Mirón PÉrez, M.D.: «Olimpia, Eurídice y el origen del culto dinástico en la Grecia helenística», $F I$ 9, 1998, 215-235.

MolinA, F.: «Quinteto para dioses músicos en la mitología griega», EClás.113, 1998, 7-35.

Molina, F.: «Pensando en los Mitos de la Música», 'Ilu 2, 1997, 99-106.

Molina, F.: «Hacia el paraíso hiperbóreo», Corolla Complutensis 505-516.

Moncrieff, A. R. H.: Mitología clásica. Traducción de P. Serrano. Barcelona, Edimat, 1998.

Montero Montero, M.: «Orfeo y Eurídice», Amores míticos 137-163.

MoREAu DE JONNES, A.: Los tiempos mitológicos: Cosmogonías, El libro de los muertos, Sanchoniaton, El Génesis, Hesiodo, El Avesta. Barcelona, Edicomunicación, 1998.

Morenilla Talens, C.: «Aquiles, héroe a su pesar», SPhV 2, 1997, 35-47.

Navarro, J.L.: «La figura de Ulises en la tragedia griega», Actas del IX Congreso IV, 265-269.

NiETo HeRnÁnDEZ, P.: «Algunas reflexiones sobre mitología griega: problemas de definición e interpretación", EClás.114, 1998, 7-39.

NiETo IbÁÑEZ, J.M.: «La mitología universal del Pseudo-Eupólemo (Eus.PE IX 18,2)», Corolla Complutensis 525-530.

Olmos Romera, R.: «El cantor y la lira. Lecturas y usos de las imágenes de Orfeo», Actas del IX Congreso VI, 3-16.

PÉrez Jiménez, A.: «Mito y astrología en Grecia: un viaje con retorno», Religión, magia y mitología 137-165.

Plácido, D.; Valdés, M.: «Eleusis, el Ática y Atenas hasta la época de Pisístrato», Corolla Complutensis 469-482.

Portulas, J.: «Tracios en Eleusis», Actas del IX Congreso IV, 289-293.

Pòrtulas, J.: «El mito y los orígenes del pensamiento griego», Religión, magia y mitología 201-220.

RAMOS JURADO, E.A.: «Mito y religión en la filosofía griega a fines del mundo antiguo», Religión, magia y mitología 221-237.

Rodríguez SOMOlinos, J.: «Ártemis Efesia en Lidia y Apolo Clario en Éfeso: mántica y propaganda religiosa en época imperial», Actas del IX Congreso VI, 207-212.

RosetTI, L.: «Il mito escatologico in Platone e il suo dubbio statuto epistemico», Religión, magia y mitología 265-282. 
RUIZ DE ElVIRA, A.: «Ónfala», CFCL 14, 1998, 27-55.

Santiago Álvarez, R.A.: «Hemeroskopeion y la epíclesis Hemera para Ártemis», Actas del IX Congreso VI, 225-230.

SCHNEIDER, M.: El origen musical de los animales-símbolos en la mitología y la escultura antiguas. Ensayo histórico-etnográfico sobre la subestructura totemística y megalítica de las altas culturas y su supervivencia en el folklore español. Madrid, Siruela, 1998.

SERRANo ESPINOSA, M.: «Acerca de los orígenes de la tauromaquia cretense», Gerión 16, 1998, 39-48.

SUÁREZ DE LA TORRE, E.: «Observaciones sobre la presencia de la mántica en la Comedia griega», La comedia griega y su influencia 177-201.

SUÁREZ DE LA TORRE, E.: "Algunos motivos de la mitología apolínea y su transfondo religioso», Religión, magia y mitología 283-330.

SUÁREZ DE LA TORRE, E.: «Observaciones sobre los rituales délficos eneatéricos», Corolla Complutensis 483-496.

Tsirkin, J.B.: «Nórax, hijo de Eritea», Polis 9, 1997, 277-283.

VAlCÁrCel MAYOR, C.: Del Olimpo al Thader, pasando por el Panteón. Murcia, Concejalía de Cultura, Festejos y Turismo, 1998.

Varias Garcia, C.: «Testimonios de Orestes y Alcmeón antes de Esquilo», Actas del IX Congreso IV, 351-355.

VELASCO LOPEZ, M.H.: «Diodoro V 28.5-6 y la creencia del alma entre los celtas», Actas del IX Congreso VI, 249-254.

Villa Polo, J.: «Pasífae y el toro», Amores míticos 81-116.

Villarrubia, A.: «Nono de Panópolis y el mito de Acteón», Habis 29, 1998, 249-268.

\section{Filosofia. Ciencia}

Bilbeny, N.: Sócrates. El saber como ética. Barcelona, Península, 1998.

BöHME, G.; BӧнмE, H.: Fuego, agua, tierra, aire. Una historia cultural de los elementos. Traducción de P. Madrigal. Barcelona, Herder, 1998.

FERNÁNDEZ GÓMEZ, M.: Ingeniería en la época clásica. Valencia, Universidad Politécnica, 1998.

GaRCía CASTILLO, P.: «Retórica y cinismo», Retórica, política e ideología I, 235-239.

HADOT, P.: ¿Qué es la filosofía antigua? Traducción de E. Cazenave Tapie Isoard. Madrid, Fondo de Cultura Económica de España, 1998.

LLEDO, E.: Imágenes y palabras. Ensayos de humanidades. Madrid, Taurus, 1998. 
LURI MEDRANO, G.: El proceso de Sócrates. Sócrates y la transposición del socratismo. Nadrid, Trotta, 1998.

Marfas, J.: Historia de la filosofía. Prólogo de X. Zubiri, epílogo de José Ortega y Gasset. Madrid, Alianza Editorial, 1998.

Martos Montiel, J.F.: «El concepto de placer en la ética estoica», F1 9, 1998, 199-213.

Medina GonZÁlez, A.: «Placer, naturaleza y autarquía en la ética epicúrea», Corolla Complutensis 433-438.

Nava Contreras, M.: «Politeia y utopía. Elementos para una poética de la utopía filosófica en Grecia», Retórica, política e ideología 1, 229-234.

PÒRTULAS, J.: «El mito y los orígenes del pensamiento griego», Religión, magia y mitología 201-220.

RAMOs JURADO, E.A.: «Mito y religión en la filosofía griega a fines del mundo antiguo», Religión, magia y mitología 221-237.

RODRÍGUEZ MORENO, I.: Ángeles, démones y héroes en el neoplatonismo griego. Amsterdam-Las Palmas, Hakkert, 1998.

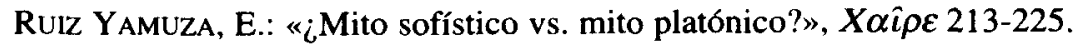

Toscano, M.; ANCOCHEA, G.: Místicos neoplatónicos, Neoplatónicos místicos. De Plotino a Ruysbroeck. Madrid, Etnos, 1998.

VílCHEZ, M.: «La filosofía preplatónica. Algunos cuestionamientos abiertos», Corolla Complutensis 405-410.

\section{Pervivencia. Humanismo. Historia de la filologia}

AgullaR, R.M.: «El mito griego en la poesia de Garcia Lorca», CFCG 8, 1988, 75-102.

AlCalde Martín, C.: «El mito de Leda: sus metamorfosis en la historia del arte», Religión, magia y mitología 9-37.

Alcina, J.F.: «El mito como poética», Actas del IX Congreso VII, 1-18.

AMADO, M.T.: «La primera traducción del griego al gallego en el Rexurdimento», Corolla Complutensis 727-736.

Álvarez BAÑos, M.I.: «Un griego nacido en irlanda: Oscar Wilde», EClás.113, 1998, 77-85.

ARANA, J.R.: «El anticartesianismo de Winckelmann», Actas del IX Congreso VII, $41-45$.

Arribas, S.: «El estilo severo de la política: Hegel y la tragedia como representación del mundo moderno", Retórica, política e ideología II, 187-191.

BALCELls, J.M.: «Consideración de la Batracomiomaquia en tratadistas y poetas españoles áureos", Actas del IX Congreso VII, 55-59. 
Barbeito, P.: «Pedro Juan Núñez, editor de Frínico», Corolla Complutensis 655-665.

BarReto Rocha, J.C.: «Retórica e Argumentação no Trabalho Filológico», Retórica, política e ideología II, 251-257.

BELTRÁN Almería, L.: «El debate sobre el género en la novela antigua», $\Delta t-$ $\delta \alpha ́ \sigma \kappa \alpha \lambda o \varsigma$ 259-278.

Beltrán Noguer, M.T.: «Mitología y música», Actas del IX Congreso VII, 61-64. Benavente, M.: «Una metáfora común a Epicarmo, Lorca y Kipling», Corolla Complutensis 751-754.

Bock CANo, L.: «El mito de Deméter y Demofonte y otros motivos clásicos en la obra de Blas Infante», Actas del IX Congreso VII, 75-78.

Bodin, J.: Coloquio de los siete sabios sobre arcanos relativos a cuestiones últimas. Colloquium Heptaplomeres. Madrid, Centro de Estudios Políticos y Constitucionales, 1998.

Bravo García, A.: «Tradición clásica, humanismo y ciencia moderna», Corolla Complutensis 617-628.

Bueno, A.: Mitología en los cielos de Madrid. Textos de C. García Gual y C. Meneses González. Barcelona, Lunwerg, 1998.

CABo Aseguinolaza, F.: El futuro de las humanidades. Valencia, Episteme, 1998.

Cañigral, L.: «Inexistencia de la Eidción 1766 de la gramática griega de Pedro Antonio Fuentes", Corolla Complutensis 721-726.

Carbón Sierra, A.B.: «José de la Luz y Caballero y la tradición clásica en Cuba», Faventia 20/1, 1998, 105-109.

Castelli, G.: "Lucifero Calaritano contro la cultura classica», Helmantica 49, 1998, 391-413.

CASTRo de CaStro, J.D.: «Algunos aspectos de vocabulario en la traducción de los Idilios de Teócrito de Vicente Mariner», Actas del IX Congreso VII, 89.93.

Châtillon, G.: Alejandreida. Edición de F. Pejenaute Rubio. Madrid, Akal, 1998.

Closa FarRés, J.: "Winckelmann y la lectura artística de Homero», $\Delta t \delta \alpha ́ \sigma-$ $\kappa \alpha \lambda \circ \varsigma 279-289$.

CORS I MEYA, J.: «L'hexàmetre homèric adaptat a la mètrica catalana en la versió de Carles Riba de l'Odissea. Presentació d'un estudi complet», Faventia 20/2, 1998, 209-217.

Cossío, J.M. DE: Fábulas mitológicas en España. 2 vols. Madrid, Istmo, 1998. EsPaÑa, R. DE: El Peplum. La antigüedad en el cine. Barcelona, Glénat, 1998. FERNÁNDEZ, A.: Dioses y mitos. Una aproximación literaria a la pintura mitológica del Museo del Prado. Madrid, Ediciones La Librería, 1998. 
Fernández Nieto, F.J.; Melero, A.; Mestre, A. (eds.): Luis Vives y el humanismo europeo. Valencia, Universidad, 1998.

Fernández Vallina, E.: «Entre Edad Media y Humanismo. El puesto del hombre en el Tostado», Actas del IX Congreso VII, 109-112.

Gallardo, M.D.: «Dos cuentos ilustrados por Picasso», Actas del IX Congreso VII, 112-115.

García JuRado, F.: «Antiguos textos de ciencia convertidos en poesía: Dioscórides y Andrés de Laguna en el Libro de los venenos de Antonio Gamoneda", Epos 13, 1997, 379-395.

García Jurado, F.; Hualde Pascual, P.: «Autores griegos y latinos como motivo literario explícito en la literatura del siglo XX. Circunstancias y diferencias de tratamiento I-II», Actas del IX Congreso VII, 121-128.

García Jurado, F.; Hualde Pascual, P.: Juan Valera. Madrid, Ediciones Clásicas, 1998.

García Macho, M.L.; SABA, A.: El léxico en la Ylíada de Homero, traducida por Juan de Mena. Madrid, Universidad Nacional de Educación a Distancia, 1998.

García Romero, F.: «Sobre Penélope de Domingo Miras», Epos 13, 1997, $55-75$.

GARCía RoMERO, F.: «Adaptaciones cinematográficas de la tragedia griega: puesta en escena antigua y moderna», Dramaturgia y puesta en escena 193-203.

GARZYA, A.: «Considerazioni sul tragico in Eschilo (e in Camus)», Corolla Complutensis 155-160.

GILABERT, P.: «¿Merecen los males del hombre contemporáneo un tratamiento “acrítico” basado en la sabiduría antigua?», EClás.114, 1998, 53-65.

GONZÁLEZ, M.S.: «La cultura clásica analizada desde la filatelia», Actas del IX Congreso VII, 137-141.

GONZÁlez MARTín, F.J.: «Retórica clásica, ideología y retórica en el discurso decimonónico español. El caso de Cánovas del Castillo», Retórica, política e ideología II, 273-280.

Guerrero Guerrero, E.: «Pedro Henríquez Ureá y el Ateneo de México: la clasicidad como criterio estético educativo», Retórica, política e ideología II, 155-160.

Guzmán Guerra, A.: «Francisco de la Reguera, traductor de los Relatos Verídicos de Luciano. Un manuscrito inédito de la $\mathrm{BN} »$, Actas del IX Congreso VII, 163-167.

Hernández GonzÁlez, F.: «Un polígrafo canario en la Patrología de Migne», Corolla Complutensis 737-744.

HeRnÁNDEZ MuÑoz, F.: «Un epigrama anónimo con el nombre de Praxíteles», Corolla Complutensis 629-634. 
HeRnÁNDEZ TORIANO, M.A.: «El mito como intertexto en la dramaturgia contemporánea: Griselda Gambaro - Sergio de Cecco - Ricardo Monti», Actas del IX Congreso VII, 169-176.

HiLdesheimer, W.: La víctima Helena. Traducción de I. Hernández. Madrid, Ediciones Clásicas, 1998.

HofMANNSTHAL, H. voN: Instantes griegos y otros sueños. Valladolid, Cuatro Ediciones, 1998.

Hualde Pascual, P.: «Documentos para la Historia de la Filología griega en la España del siglo XIX: La censura de gramáticas y traducciones del griego y la Real Academia Grecolatina (1830-1833)», Epos 13, 1997, 397416.

Jens, W.: Sófocles y Brecht (Talk Show). Edición crítica a cargo de K. Andersen y J.V. Bañuls. Valencia, Universidad, 1998.

JiMÉNEZ FERnÁNDEZ, J.: «Tres frases tópicas de origen griego en nuestra lengua», Corolla Complutensis 745-750.

Krajeswska-WieczoreK, A.: «Antigone and the politics of Modern Metropolis. J. Glowacki's Play on the Homeless: Antigone in New York», Retórica, política e ideología $I I, 137-141$.

KRAYE, J. (ed.): Introducción al humanismo renacentista. Edición española a cargo de C. Clavería. Traducción de Ll. Cabré. Madrid, Cambridge University Press, 1998.

KRAYE, J. (ed.): Introducción al humanismo renacentista. Madrid, Cambridge University Press, 1998.

Lillo Redont, F.: «El mundo clásico en la poesía gallega de Eduardo Pondal», EClás.113, 1998, 59-76.

Lloyd-Jones, K.: «Eloquence in the Age of Printing: Étienne Dolet and Classical Rhetoric», Retórica, política e ideología II, 27-33.

LÓPEZ FÉREZ, J.A.:"Estudio sobre la influencia de la comedia griega en la literatura española», La comedia griega y su influencia 387-455.

LÓPEZ Férez, J.A.; Roura RoIG, C.: Influencias de la mitología clásica en la literatura española e hispanoamericana del siglo XX: guía didáctica. Madrid, Universidad Nacional de Educación a Distancia, 1998.

López Grigera, L.: Anotaciones de Quevedo a la Retórica de Aristóteles. Salamanca, s.n., 1998.

LÓPEZ RODRíguez, C.: «La función de los mitos griegos en la poesía de Luis Cernuda», Religión, magia y mitología 101-122.

LÓPEZ TORRIJOS, R.: Mitología e Historia en las obras maestras del Prado. Madrid, Celeste, 1998.

Luján Martínez, E.R.: «Los devaneos de Erato: el mundo clásico de Ana Rosetti», Epos 13, 1997, 77-88. 
Mariño SánChez-Elvira, R.M.: «Los temas griegos en Deseo bajo los olmos de E. O'Neill», Actas del IX Congreso VII, 207-210.

Martínez Benavides, M.J.: «La filosofía de Platón en el Renacimiento a través de un intermediario", Fortunatae 9, 1997, 81-101.

Martínez Conesa, J.A.: Remembranzas clásicas en D. Miguel de Unamuno», Corolla Complutensis 755-762.

Martínez Manzano, T.: «Dos traducciones renacentistas de Plutarco inéditas», Actas del IX Congreso VII, 223-228.

Martínez Manzano, T.: «Los escolios aristofánicos del Matr.4629 y el humanismo griego del Quattrocento», Corolla Complutensis 579-582.

MARTínez Manzano, T.: Constantino Láscaris: semblanza de un humanista bizantino. Madrid, Consejo Superior de Investigaciones Científicas, 1998.

Morales Ortiz, A.: «Pedro Juan Núñez, traductor de Plutarco», Actas del IX Congreso VII, 253-257.

Moreno García, A.; Limburg, K.: «Comentario a Mat 10,16 de Pedro de Valencia. Un manuscrito inédito de la Biblioteca Nacional de Madrid», $\mathrm{Hel}$ mantica 49, 1998, 247-266.

Moormann, E.M.; VitTerhoeve, W.: De Adriano a Zenobia. Temas de la historia clásica en la literatura, la música, las artes plásticas y el teatro. Madrid, Akal, 1998.

NAVARRETE ORCERA, A.R.: «La mitología a través de la pintura: nueva recensión bibliográfica», EClás.114, 1998, 77-118.

Navarro, M.: «De la casa de Agatón a La montaña mágica», Actas del IX Congreso VII, 269-274.

Ozaeta Gálvez, M.A.: «Medea en Cherubini», EClás.114, 1998, 67-73.

PERAL VEGA, E.J.: «La zarzuela de la primera mitad del siglo XVIII: deformación burlesca de la mitología clásica», $C F C L$ 14, 1998, 223-243.

PÉrez García, N.: «Dos tópicos clásicos en la poesía española del último tercio del siglo XX», CFCL 14, 1998, 301-309.

Picklesimer, M.L.: «Antígona: de Sófocles a María Zambrano», FI 9, 1998, 347-376.

Pino Campos, L.M.: «Graecorum philosophorum aurea dicta. Selección de apotegmas (4. ${ }^{\text {a }}$ parte)", Fortunatae 9, 1997, 125-139.

PociÑA, A.: «La nave de la sorpresa: una escena de los Argonautas en Lucio Acio y en Lope de Vega», Actas del IX Congreso VII, 299-303.

PoCiña LóPEZ, A.J.: «Pervivencia del mundo clásico en el Auto das Fadas de Gil Vicente», Actas del IX Congreso VII, 295-298.

RAMÓN PALERM, V.: "Cervantes y la retórica clásica: estado de la cuestión», Retórica, política e ideología II, 91-96. 
Real Torres, C.: «La contribución de Alfonso de Palencia a la difusión de las doctrinas humanistas en España», Actas del IX Congreso VII, 317-320.

RAYMOND, J.C.: «Rhetoric, Politics and Ideology: Three Definitions», Retórica, política e ideología II, 193-201.

Renero Arribas, V.M.: Alcibiades. La ambición del poder. Madrid, Aldebarán, 1998.

RIDING, L.: Final troyano. Barcelona, Salvat, 1998.

Rivas RoDRíGUEZ, M.C.: «Una propuesta didáctica: tras las huellas de Orfeo», Religión, magia y mitología 239-263.

Roca, I.: «J. Luis Vives; lexicólogo en sus Comentarios a La ciudad de Dios», Actas del IX Congreso VII, 321-325.

Rodríguez AdRADOS, F.: «Volvamos al léxico y la sintaxis de los manuscritos. A propósito de Eurípides, Medea y Cíclope», Actas del IX Congreso IV, 317-322.

Romojaro, R.: Lope de Vega y el mito clásico. Málaga, Universidad, 1998.

Romojaro, R.: Las funciones del mito clásico en el Siglo de Oro. Garcilaso, Góngora, Lope de Vega, Quevedo. Barcelona, Anthropos, 1998.

RotTERDAM, E. DE: Apotegmas de sabiduría antigua. Edición de M. Money. Barcelona, Edhasa, 1998.

RuIz DE ElviRA, M.R.: «Afrodita/Venus: amores y descendencia», Actas del IX Congreso VII, 327-331.

RUIZ DE ElVIRA, A.: «Universitas y Encyclopaedia (II)», Habis 29, 1998, 349-369. Ruiz Gito, J.M.: «La traducción del Maestro Gaspar Hernández, un manuscrito desconocido en la tradición de La Tabla de Cebes en España», Actas del IX Congreso VII, 338-344.

Salas Salgado, F.: «Epigramas latinos sobre tema griego de Juan de Iriarte», Corolla Complutensis 709-720.

Santana Henríquez, G.: «Hacia una tipología mítica en las obras teatrales de Tirso de Molina: los monstruos (I)», Corolla Complutensis 679-686.

Segura Munguía, S.: Cultura clásica y mundo actual. Bilbao, Zidor Consulting, 1997.

SEISDEDos SÁnchez, C.: «De falso credita et ementita Constantini donatione Declamatio de Lorenzo Valla. Retórica e ideología en el siglo XV», Retórica, política e ideología II, 179-186.

SERRANO DE LA TORRE, J.M.: «Tradición clásica y poesía áurea», $A M 21,1998$, 315-331.

Signes Codoñer, J.: «La fundación de Asimov y el mundo antiguo», Corolla Complutensis 771-780.

Tato Ozaeta, A.: Epilio de Hibris como Faetón el Resplandeciente. Madrid, s.n., 1998. 
TORTOSA, M.D.: «El tratamiento de la mitología clásica en la poesía española del siglo XVIII», Religión, magia y mitología 331-349.

VIVES, J.L.: El arte retórica. De ratione dicendi. Estudio introductorio de $\mathrm{E}$. Hidalgo Serna. Edición, traducción y notas de A.I. Camacho. Barcelona, Anthropos, 1998.

12. Diccionarios. Repertorios. OtRos inStRUMENTOS

AA.VV.: «Bibliografía lingüística española 1992-1996», R.S.E.L. 28, 1998, 487-628.

CuARTERo IBORRA, F.J.: «Bibliografía del prof. Manuel Balasch», Faventia 29/2, 1998, 9-12.

EsPEjo Muriel, C.: «La Historia Antigua y las nuevas tecnologías: internet», FI 9, 1998, 141-152.

Estébanez García, F.: Étimos griegos. Monemas básicos de léxico científico. Barcelona-Valencia, Octaedro-Nau Llibres, 1998.

LEE, J.A.L.; HoRSLEY, G.H.R.: «A Lexicon of the New Testament with Documentary Parallels: Some Interim Entries. 2», FN 11(21-22), 1998, 57-83.

Martínez lópez, F.J.; Luna Huertas, P.; Fernández Carrión, R.; SalmeRÓN SILVERA, J.K.: Internet para investigadores. Relación y localización de recursos en la red para investigadores y universitarios. Huelva, Universidad, 1998.

Morillas, E.; ARIAS, J.P.: El papel del traductor. Salamanca, Colegio de España, 1998.

Morón Arroyo, C.: Las humanidades en la era tecnológica. Oviedo, Nobel, 1998.

RAMÓN PAlerm, V. (ed.): Plutarco de Queronea. Bibliografía española. Madrid, Ediciones Clásicas, 1998.

REPERTORIO BIBLIOGRÁfICO DE LA LEXICOGRAFIA GRIEGA (RBLG). Redactado por P. Boned Colera. Revisado, corregido y aumentado por J. Rodríguez Somolinos con la colaboración de E. Vallines Menéndez, J. Martínez de Tejada Garaizábal y E. Luján Martínez. Diccionario Griego-Español, Anejo III. Madrid, Consejo Superior de Investigaciones Científicas, 1998.

Martínez Pinna, J.; Montero Herrero, S.; Gómez Pantoja, J.: Diccionario de personajes históricos griegos y romanos. Madrid, Istmo, 1998.

Riaño RuFILANCHAS, D.: Aplicaciones de Macintosh a la filología clásica. Madrid, Ediciones Clásicas, 1998.

RodríGuEz SOMOLINOS, H.: «Publicaciones sobre Filología Griega en España: 1996», Epos 13, 1997, 449-488. 
San Ginés Agullar, P.: Traducción teórica. Planteamientos generales y teóricos de la traducción. Granada, Comares, 1998.

Vicuña, J.; SANZ DE AlmaRza, L.: Diccionario de los nombres propios griegos, debidamente acentuados en español. Madrid, Ediciones Clásicas, 1998.

Vega, M.J.; CARBONELl, N.: La literatura comparada: principios y métodos. Madrid, Gredos, 1998.

Vocabulario grIEgo del Nuevo Testamento. Salamanca, Sígueme, 1998.

\section{DidÁCTICA}

Aparicio, J.A.; Balme, M.; Juanes, J.I.; Lawall, G.: Griego. Introducción al griego clásico. Bachillerato: humanidades y ciencias sociales. Madrid, Oxford University Press España, 1998.

ARTERo, A. ET Alil: Odisea 6. Texto, comentarios y traducción. Almería, Consejería de Educación y Ciencia de la Junta de Andalucía, 1998.

BARDI, P.: Atlas del mundo clásico. Grecia y Roma en la Antigüedad. Madrid, Anaya, 1998.

Camacho Ruiz, M.: Griego. Consejería de Educación y Ciencia de la Junta de Andalucía, 1998.

CAPELLÀ SOLER, M.: Grec, Batxillerat: modalitat humanitats $i$ ciències socials. Barcelona, Teide, 1998.

Casasús, A.: Griego II, COU. Guía didáctica. Valencia, Instituto de Bachillerato a Distancia de la Comunidad Valenciana, 1998.

Caudet Yarza, F.: Leyendas de Grecia y Roma. Madrid, Edimat, 1998.

Colomer Corbaton, R.M.; Tomás Budó, M.R.: Grec 1. Batxillerat. Modalitat humanitats $i$ ciències socials. Barcelona, Castellnou, 1998.

De Crescenzo, L.: Nadie. La Odisea relatada por los lectores de hoy. Traducción de A. Pentimalli. Barcelona, Seix Barral, 1998.

Esteban, A.; AGUIRRE, M.: Cuentos de la mitología griega III. En el mar. Ilustraciones de S. López. Madrid, Ediciones de La Torre, 1998.

FERnÁNDEZ, A.J.: Dramatizaciones de mitos y leyendas griegas. Ciudad Real, Ñaque, 1998.

Garcia Gual, C.; lucas, J.M.; Morales Otal, C.: Griego 1: Bachillerato. Madrid, Santillana, 1998.

Homero: La Iliada o El sitio de Troya. Presentación de L.A. de Cuenca. Prólogo de J. García Padrino. Versión de M.L. Morales. Madrid, Anaya, 1998.

Homero: La Odisea. Presentación de L.A. de Cuenca. Madrid, Anaya, 1998. 
Lucía, A.; Blaya, R.; Sarabia, E.: Diuturna III. Cultura Clásica. $2{ }^{\circ}$ ciclo de ESO. Barcelona, Octaedro, 1998.

Macías Villalobos, C. (Equipo Alta Axarquía): Griego $\left(1 .^{\circ}\right.$ y $2 .^{\circ}$ de Bachillerato). Madrid, McGraw-Hill, 1998.

Martínez, M.; Pino Campos, L.M.; Santana Henríquez, G.: Los mitos de Platón. Antología de Textos. Santa Cruz de Tenerife, Consejería de Educación, 1998.

PARdo MAdRIGAL, D.: La enseñanza del griego en el Bachillerato: propuesta de secuenciación y unidades didácticas. Fuenlabrada, CPR de Fuenlabrada, 1998.

Platón: Mitos. Prólogo de C. García Gual. Traducción de C. García Gual, J. Calonge, E. Lledó y otros. Selección y actividades por F. García Moriyón. Madrid, Siruela, 1998.

RAMÓN PALERM, V.: «La lengua literaria de Aristófanes: aspectos didácticos», $\Delta t \delta \alpha \sigma \kappa \alpha \lambda \circ \varsigma 63-98$.

Rivas RodríGUEZ, M.C.: «Una propuesta didáctica: tras las huellas de Orfeo», Religión, magia y mitología 239-263.

SutCliff, R.: Las aventuras de Ulises. La historia de la Odisea de Homero. Introducción de C. García Gual. Notas, glosario y actividades por M. Otero. Traducción de J.L. López Muñoz. Barcelona, Vicens Vives, 1998. 